A N N A L E S

UNIVERSITATIS MARIAE CURIE-SKŁODOWSKA

LUBLIN - POLONIA

VOL. LXIII, 1

SECTIO G

2016

Uniwersytet Marii Curie Skłodowskiej w Lublinie

edyta.lis@poczta.umcs.lublin.pl

EDYTA LIS

\title{
Rola UE i NATO w systemie bezpieczeństwa międzynarodowego
}

The Role of European Union and NATO in the System of the International Security

\section{WPROWADZENIE}

Zapewnienie bezpieczeństwa w Europie stanowi cel działania takich organizacji międzynarodowych, jak Organizacja Traktatu Północnoatlantyckiego (NATO), Organizacja Bezpieczeństwa i Współpracy w Europie (OBWE), a także Unii Europejskiej (UE)1. Tworzą one unikalne na skalę światową instytucje bezpieczeństwa regionalnego. Relacje pomiędzy organizacjami międzynarodowymi opierają się nie tylko na współdziałaniu, ale i na współzawodnictwie². Współpracę pomiędzy UE a NATO w dziedzinie międzynarodowego pokoju i bezpieczeństwa można określić jako trudną i złożoną ${ }^{3}$.

Należy zauważyć, że skuteczne zwalczanie występujących obecnie zagrożeń w postaci terroryzmu międzynarodowego, proliferacji broni masowego rażenia, przestępczości zorganizowanej czy cyber-zagrożeń skłania do podejmowania efektywnej współpracy pomiędzy istniejącymi organizacjami,

1 Zob. G. Aybet, A European Security Architecture after the Cold War: Questions of Legitimacy, Palgrave Macmillan 2000, DOI: http://dx.doi.org/10.1057/9780230598553.

2 Zob. A.D. Rotfeld, The OSCE Role in Cooperation in NATO and the UE in Southeastern Europe, "Croatian International Relations Review" 2000, Vol. 6, No. 21/22, s. 99.

3 J. Medcalf, Cooperation between the EU and NATO, "Studies in Contemporary History and Security Policy" 2003, Vol. 11, No. 1, s. 95. 
w tym między UE i NATO. Organizacje te powinny kompleksowo podchodzić do kwestii bezpieczeństwa i dążyć do określenia najważniejszych zadań w tej dziedzinie ${ }^{4}$.

\section{ROZWÓJ WSPÓŁPRACY UE Z NATO}

NATO powołano do życia w 1949 r. jako organizację bezpieczeństwa zbiorowego ${ }^{5}$, natomiast pierwszą Wspólnotę - Europejską Wspólnotę Węgla i Stali - utworzono na podstawie traktatu z $1951 \mathrm{r} .{ }^{6}$ NATO i Wspólnoty Europejskie powstały zatem w okresie zimnej wojny, ale w tym czasie Wspólnoty ograniczały się głównie do integracji o charakterze gospodarczym, natomiast NATO miało być gwarantem bezpieczeństwa europejskiego ${ }^{7}$. Państwa Europy Zachodniej podjęły także próby ustanowienia ram współpracy w dziedzinie bezpieczeństwa poza NATO, np. po zmianach Traktatu Brukselskiego z 1948 r., na mocy Układów paryskich w 1954 r. powstała Unia Zachodnioeuropejska (UZE) ${ }^{8}$, dążono do utworzenia Europejskiej Wspólnoty Obronnej ${ }^{9}$. W ramach Europejskiej Współpracy Politycznej w latach 70. i 80. XX w. określano wspólne cele Wspólnot w zakresie polityki zagranicznej ${ }^{10}$. UE została ustanowiona na mocy postanowień Traktatu z Maastricht ${ }^{11}$, który przewidywał, że jej II filarem jest Wspólna Polityka Zagraniczna i Bezpieczeństwa (WPZiB). Pojawiły się wprawdzie obawy, czy ustanowienie tego filaru nie doprowadzi do osłabienia $\mathrm{NATO}^{12}$, ale wojna na Bałkanach

4 A. Pop, NATO and the European Union: Cooperation and Security, "NATO Review" 2007, www.nato.int/docu/review/2007/Partnerships_Old_New/NATO_EU_cooperation_security/EN/index.htm [data dostępu: 20.08.2016]. Zob. S. Silvestri, The UE, NATO, and the Use of Force: A Division of Labour, [w:] What Do Europeans Want from NATO?, ed. A. de Vasconcelos, European Union Institute for Security Studies, Report No. 8, November 2010, s. 16-18.

5 Dz.U. z 2000 r., nr 87, poz. 970.

6 http://oide.sejm.gov.pl/oide/index.php?option=com_content\&view=article\&id=14815:trak taty\&catid=22\&Itemid=940\#D [data dostępu: 20.08.2016].

7 Zob. J. Sperling, The European Union and NATO: Subordinate Partner, Cooperative Pillar, Competing Pole, [w:] The EU Presence in International Organizations, eds. S. Blavoukos, D. Bourantonis, Routledge 2011, s. 33.

8 E. Cziomer, Instytucjonalizacja wspótpracy transatlantyckiej: problemy $i$ wyzwania, [w:] Bezpieczeństwo międzynarodowe w XXI wieku. Wybrane problemy, Kraków 2010, s. $41-42$.

9 A. Moens, European Defence and NATO: the Case for New Governance, "International Journal" 2001, Vol. 56, No. 2, s. 261. Zob. J.G. McLaren, Europe's Efforts to Develop an Autonomous Defense Capability. A Constitution for Europe, and the Implications for NATO, "Columbia Journal of European Law" 2005, Vol. 11, No. 3, s. 523-525.

10 A. Moens, op. cit., s. 261.

${ }_{11}$ Dz.Urz. WE C 224, 31.08.1992.

${ }_{12}$ R. Adler-Nissen, The European Security and Defence Policy: from Distant Dream to Joint Action, [w:] International Organizations: Their Role in Conflict Management, ed. P. Dahl Thruelsen, Royal Danish Defence College, Copenhagen 2009, s. 69. Zob. A. Baggett, Development of the 
w początkach lat $90 . \mathrm{XX}$ w. wskazała na konieczność rozwoju politycznych i militarnych zdolności UZE w celu zwalczania sytuacji kryzysowych, które nie stanowiły zagrożenia dla integralności terytorialnej państw członkowskich NATO. Konflikt bałkański przyczynił się także do przeprowadzenia zmian w ramach NATO, np. w strukturze dowodzenia. W ich rezultacie UE i NATO w dziedzinie zarządzania kryzysowego stały się raczej konkurentami niż partnerami ${ }^{13}$. Na spotkaniu ministerialnym Rady Północnoatlantyckiej w 1996 r. w Berlinie ${ }^{14}$ zaproponowano budowę Europejskiej Tożsamości Bezpieczeństwa i Obrony w ramach NATO. Uzgodniono ponadto, że zasoby NATO będzie można wykorzystywać w operacjach prowadzonych przez UZE.

Traktat amsterdamski ${ }^{15}$ wzmocnił instytucje WPZiB, proces decyzyjny, a także inkorporował zadania petersberskie do Traktatu o Unii Europejskiej ${ }^{16}$. W dniu 4 grudnia 1998 r. na brytyjsko-francuskim szczycie w Saint-Malo przyjęto wspólną deklarację dotyczącą bezpieczeństwa europejskiego, w której stwierdzono, że UE powinna w przyszłości uzyskać autonomiczną zdolność do podjęcia działań, wspartych siłami militarnymi, w celu odpowiedzi na kryzysy międzynarodowe ${ }^{17}$. Należy podkreślić, że wspólna deklaracja nie oznaczała przyjęcia w tej kwestii wspólnej polityki ${ }^{18}$. Zdaniem Brytyjczyków własna polityka bezpieczeństwa i obrony UE mogłaby doprowadzić do wycofania się USA z kontynentu, natomiast Francuzi uważali, że tylko dzięki takiej polityce mogą stać się dla USA liczącym się partnerem ${ }^{19}$.

W tym kontekście dla rozwoju WPZiB istotne było też stanowisko USA. Sekretarz Stanu M. Albright przedstawiła je w słynnym oświadczeniu $3 \mathrm{D}^{20}$.

European Union Common Defense and Its Implications for the United States and NATO, "Georgia Journal of International and Comparative Law" 2003, Vol. 31, No. 2, s. 357.

13 A. Moens, op. cit., s. 261-262.

${ }^{14}$ Final Communiqué of the Ministerial Meeting of the North Atlantic Council, Press Communiqué M-NAC-1(96)63 - 3 June 1996.

15 Dz.U. z 2004 r., nr 90, poz. 864/31.

16 J. Wouters, F. Neart, How Effective is the European Security Architecture? Lesson from Bosnia and Kosovo, "International and Comparative Law Quarterly" 2001, Vol. 50, No. 3, DOI: http:// dx.doi.org/10.1093/iclq/50.3.540, s. 545.

17 www.atlanticcommunity.org/Saint-Malo\%20Declaration\%20Text.html [data dostępu: 20.08.2016]. Zob. M. Reichard, Some Legal Issues Concerning the EU-NATO Berlin Plus Agreement, "Nordic Journal of International Law" 2004, Vol. 73, No. 1, DOI: http://dx.doi. org/10.1163/157181004323056383, s. 41.

18 A. Deighton, Through the Glass Ceiling: The EU as Developing Security Regime for Europe?, "Croatian International Relations Review" 2000, Vol. 6, No. 20/21, s. 109.

19 R. Adler-Nissen, op. cit., s. 57.

${ }^{20}$ Madelein K. Albright, US Secretary of State 'The Right Balance Will Secure NATO's Future,' "Financial Times", 7 December 1998, [w:] From St-Malo to Nice European Defence: Core Documents, compiled M. Rutten, "Chaillot Papers" May 2001, No. 47, s. 10-12. Por. EUUS Summit, Joint Statement, Brussels, 26 March 2014, 140326/02, pkt. 30-33. We wspólnym 
Podkreślono w nim, że Stany Zjednoczone popierają politykę obronną UE przy spełnieniu trzech warunków: nieodseparowywania USA od Europy, niedyskryminowania państw członkowskich NATO, które nie są jednocześnie członkami UE, niepowielania zasobów $\mathrm{NATO}^{21}$.

Znaczący postęp we wzajemnych relacjach nastąpił podczas szczytów Rady Europejskiej w Kolonii ${ }^{22}$, Helsinkach ${ }^{23}$ i Santa Maria de Feira ${ }^{24}$. Kryzys w Kosowie w 1998 r. uświadomił UE jej słabość militarną i zależność od zasobów USA ${ }^{25}$. W związku z tym w kwietniu 1999 r., w trakcie szczytu NATO w Waszyngtonie, uruchomiono Inicjatywę dotyczącą zdolności obronnych (Defence Capabilities Initiative) ${ }^{26}$, która umożliwiała dostosowanie się do nowej koncepcji strategicznej NATO. W szczególności zwrócono uwagę na: dowodzenie i kontrolę, system informacyjny, zdolność do współpracy, standaryzację, zdolności wojskowe europejskich sojuszników ${ }^{27}$.

Rada Europejska w Kolonii przyjęła deklarację dotyczącą rozwoju Europejskiej Polityki w zakresie Bezpieczeństwa i Obrony. Podkreślono, że UE powinna mieć zdolność do autonomicznego działania wspartego siłą militarną, tak by w razie sytuacji kryzysowych mogła realizować zadania petersberskie bez jakiegokolwiek uszczerbku w odniesieniu do akcji podejmowanych przez NATO. W związku z tym niezbędne było włączenie określonych zadań UZE do UE. Zwrócono uwagę na konieczność ustalenia, czy operacje UE będą prowadzone z wykorzystaniem zasobów NATO, czy też nie. W tym ostatnim przypadku UE miała korzystać z narodowych i wielonarodowych środków ${ }^{28}$. Rada uznała, że możliwe jest współdziałanie z NATO, ale kwestią otwartą pozostawała możliwość prowadzenia samodzielnych operacji przez $\mathrm{UE}^{29}$.

oświadczeniu z aprobatą odniesiono się do wzmocnienia przez UE Wspólnej Polityki Bezpieczeństwa i Obrony (WPBiO). USA udzieliły wsparcia dla współpracy UE z NATO. Podkreśliły, że istotną rolę odgrywa silna, spójna i oparta na wzajemnych korzyściach współpraca, uwzględniająca autonomię decyzyjną i proceduralną UE z NATO. Wyrażono potrzebę wzmocnienia praktycznej współpracy USA z UE w dziedzinie zarządzania kryzysowego, w szczególności w Afryce.

${ }_{21}$ Zob. D. Keohane, ESDP and NATO, [w:] European Security and Defence Policy. The First 10 Years (1999-2009), eds. G. Grevi, D. Helly, D. Keohane, European Union Institute for Security Studies, Paris 2009, s. 128; E. Gross, Peacebuilding in 3D: EU and US Approaches, "Chaillot Papers" 2013, No. 130, s. 7-52.

${ }^{22}$ www.europarl.europa.eu/summits/kol2_en.htm [data dostępu: 20.08.2016].

${ }^{23}$ www.europarl.europa.eu/summits/hel1_en.htm [data dostępu: 20.08.2016].

${ }^{24}$ www.europarl.europa.eu/summits/fei1_en.htm [data dostępu: 20.08.2016].

25 A. Baggett, op. cit., s. 360-362.

${ }^{26}$ Washington Summit Communique, Issued by the Heads of State and Government participating in the meeting of the North Atlantic Council in Washington, D.C. on 24th April 1999, NAC-S (99)64, pkt 4.

27 Zob. A. Deighton, op. cit., s. 110.

${ }_{28}$ Zob. Annex III, pkt 1; M. Oaks, European Defence: From Pörtschach to Helsinki, House of Commons Library, Research Paper 00/20, 21 February 2000, s. 23-28.

29 A. Baggett, op. cit., s. 363. 
Podczas szczytu w Helsinkach podjęto wiele decyzji dotyczących powołania do życia organów politycznych i wojskowych ${ }^{30}$, wzorowanych na strukturze Sojuszu, tworząc Komitet Polityczny i Bezpieczeństwa (KPiB), Komitet Wojskowy UE (KWUE) ${ }^{31}$, Sztab Wojskowy UE (SWUE). Komitet Wojskowy jest najwyższym organem wojskowym działającym w ramach Rady. W jego skład wchodzą szefowie sztabów państw członkowskich. Do jego zadań należy doradztwo wojskowe dla KPiB oraz nadzór wojskowy nad europejskim personelem wojskowym. Komitet Wojskowy sprawuje kierownictwo nad operacjami za pośrednictwem Dowódcy operacyjnego UE. W skład SWUE wchodzi personel wojskowy oddelegowany przez państwa członkowskie UE oraz personel Sekretariatu Generalnego Rady, a jego zadania obejmują wczesne ostrzeganie, ocenę sytuacji i planowanie strategiczne. Komitet Wojskowy odpowiada także za koordynację i łączność z NATO ${ }^{32}$. Zadania KPiB obecnie reguluje art. 38 Traktatu o UE, który stanowi, że Komitet sprawuje kontrolę polityczną i strategiczne kierownictwo nad operacjami zarządzania kryzysowego, obserwuje sytuację międzynarodową i przyczynia się do określania polityk ${ }^{33}$.

Rada Europejska w Helsinkach określiła relacje UE, UZE i NATO oraz zajęła się sprawą udziału państw nieczłonkowskich UE w akcjach podejmowanych w celu zwalczania sytuacji kryzysowych w przypadkach, gdy NATO nie podjęło stosownych działan ${ }^{34}$. Przewidziano także powołanie Europejskich Sił Szybkiego Reagowania dla realizacji zadań petersberskich. UE zobowiązała się, że do 2003 r. będzie zdolna do wysłania w ciągu 60 dni w rejon kryzysu sił wojskowych składających się z 50-60 tys. żołnierzy gotowych do pełnego wykonania misji petersberskich oraz działania przynajmniej przez rok w rejonie kryzysu ${ }^{35}$.

Podczas szczytu w Santa Maria de Feira przyjęto szczegółowe postanowienia dotyczące zdolności wojskowych, udziału państw nieczłonkowskich w operacjach zarządzania kryzysowego, zasady współpracy UE z NATO oraz kwestię

${ }^{30}$ Helsinki European Council, 10 and 11 December 1999, Presidency Conclusion, Annex 1 to annex IV on - Strengthening the Common European Policy on Security and Defence (Decisionmaking). Szerzej: M. Reichard, op. cit., s. 121-224.

${ }^{31}$ Council Decision of 22 January 2001 setting up the Military Committee of the European Union, Official Journal (OJ) L 27/4, 30.01.2001.

${ }^{32}$ P. Koutrakos, EU International Relations Law, Modern Studies in European Law, Bloomsbury, Hart Publishing 2015, s. 454-456.

33 Wersje skonsolidowane Traktatu o funkcjonowaniu UE i Traktatu o UE znajdują się w Dz.Urz. UE, C 326, 26.10.2012.

${ }^{34}$ Zob. II. Common European Policy on Security and Defence, pkt. 25-29, Annex IV; M. Oaks, op. cit., s. 32-38.

${ }^{35}$ Zob. H. Binnendijk, D.C. Gompert, R.L. Kugler, New Military Framework for NATO, "Defense Horizons" 2005, Vol. 48, [w:] New Military Framework for NATO: Reprint of an Issue of Defense Horizons, May 2005, Vol. 48, Diane Publishing 2008, s. 14. 
cywilnych aspektów zarządzania kryzysowego, w tym udział sił policyjnych ${ }^{36}$. Raport Prezydencji nicejskiej z 2000 r., dotyczący Europejskiej Polityki Bezpieczeństwa i Obrony (EPBiO), wskazuje natomiast, że UE zaangażowała się we wdrożenie porozumienia z NATO ${ }^{37}$.

Decyzję dotyczącą współpracy w dziedzinie bezpieczeństwa podjęto w dniu 21 stycznia 2001 r., kiedy Sekretarz Generalny NATO i Prezydencja UE (na piśmie) określili zakres współpracy i sposoby przeprowadzania wspólnych konsultacji ${ }^{38}$. W grudniu $2001 \mathrm{r}$. w trakcie szczytu w Leaken postanowiono uruchomić Plan działania dotyczący europejskich zdolności ${ }^{39}$, w którym podkreślono potrzebę koordynacji działań pomiędzy państwami członkowskimi i współpracy z NATO, tak by uniknąć powielania działań oraz zapewnić ich transparentność i spójność. Zobowiązano też państwa członkowskie UE do podniesienia zdolności wojskowych w celu skutecznego reagowania na sytuacje kryzysowe ${ }^{40}$.

Podstawowymi dokumentami dotyczącymi strategicznego partnerstwa pomiędzy UE a NATO są ${ }^{41}$ : Deklaracja UE-NATO dotycząca EPBiO z dnia 16 grudnia 2002 r. $^{42}$, zawarte 17 marca 2003 r. Porozumienia „Berlin plus”43. Należy podkreślić, że w latach 1999-2002 Turcja, a następnie Grecja blokowały inicjatywy zawarcia stosownego porozumienia, które umożliwiłoby UE korzystanie z zasobów i zdolności NATO ${ }^{44}$. Z kolei podczas szczytu NATO w Pradze w listopadzie 2002 r. została przedstawiona koncepcja powołania sił szybkiego reagowania - NATO Response Force (NRF), którą przyjęli w czerwcu 2003 r. ministrowie obrony państw członkowskich NATO, a w październiku 2004 r. ogłoszono ich gotowość operacyjną ${ }^{45}$.

${ }^{36}$ C. Common European Security and Defence Policy, pkt. 6-12; Annex I.

37 A. Missorili, EU-NATO Cooperation in Crisis Management: No Turkish Delight for ESDP, "Security Dialogue" 2002, Vol. 33, No. 1, s. 16.

38 The NATO-UE Strategic Partnership, s. 3, www.nato.int/docu/comm/2004/06-istanbul/ press-kit/006.pdf [data dostępu: 20.08.2016].

39 B. Schmitt, European Capabilities Action Plan (ECAP), European Union Institute for Security Studies, http://bdi.mfa.government.bg/info/Module\%2002\%20\%20Diplomacia\%20na\%20ES/ dopalnitelna\%20literatura/ECAP\%20process.pdf [data dostępu: 20.08.2016]. Zob. 2386 ${ }^{\text {th }}$ Council meeting - GENERAL AFFAIRS - Brussels, 19-20 November 2001, 13802/01 (Presse 414-G) Excerpt, III. European Capability Action Plan, pkt. 9-12, s. 4-6.

${ }^{40} 2386^{\text {th }}$ Council meeting - GENERAL AFFAIRS - Brussels, 19-20 November 2001, 13802/01 (Presse 414-G) - Excerpt, III. European Capability Action Plan, pkt 10, s. 4.

${ }^{41} \mathrm{http}: / /$ eur-lex.europa.eu/legal-content/PL/TXT/?uri=URISERV:133243 [data dostępu: 20.08.2016].

$42 \mathrm{http}: / /$ eu-un.europa.eu/articles/en/article_1871_en.htm [data dostępu: 20.08.2016].

$43 \mathrm{http}: / /$ eur-lex.europa.eu/legal-content/EN/TXT/?uri=URISERV:133243 [data dostępu: 20.08.2016]. Szerzej: M. Reichard, op. cit., s. 37-67.

${ }^{44}$ F. Cameron, The EU and International Organisations: Partners in Crisis Management, "European Policy Center Issue Paper", 24 October 2005, No. 41, s. 22.

${ }_{45}$ www.nato.int/cps/en/natolive/topics_49755.htm [data dostępu: 20.08.2016]. Zob. G. Lasconjarias, The NRF: from a Key Driver of Transformation to a Laboratory of the Connect Forces Initiative, 
W Deklaracji potwierdzono możliwość korzystania przez UE z zasobów planowania NATO w celu prowadzenia własnych operacji i powtórzono zasady polityczne strategicznego partnerstwa: efektywne, wzajemne konsultacje; równość i należyty wzgląd na autonomię decyzyjną UE i NATO; uwzględnienie interesów państw członkowskich UE i NATO; przestrzeganie zasad Karty Narodów Zjednoczonych; spójny, transparenty i w sposób wzajemnie wzmacniający się rozwój niezbędnych zdolności wojskowych. W Porozumieniach „Berlin plus” ustalono podstawy współpracy NATO i UE w zarządzaniu kryzysowym, umożliwiając UE - w przypadku prowadzenia przez nią operacji - korzystanie ze wspólnych zasobów i zdolności NATO, w tym dotyczących dowodzenia i wsparcia w planowaniu operacyjnym ${ }^{46}$. Porozumienia „Berlin plus” to pakiet około $15^{47}$ (w większości tajnych) porozumień instytucjonalnych zawartych pomiędzy UE a NATO, które umożliwiają im bezpieczną wymianę informacji i określają sposób, w jaki NATO udostępnia UE własne zasoby ${ }^{48}$. W maju 2003 r. w celu zapewnienia spójności i wzajemnego wsparcia w rozwoju zdolności UE i NATO powołano Grupę ds. zdolności UE-NATO. Wspomaga ją powstała w 2004 r. Europejska Agencja Obrony ${ }^{49}$.

W związku z kryzysem w Iraku w 2003 r. Wielka Brytania, Francja i Niemcy określiły ramy nowego kompromisu dotyczącego EPBiO oraz stosunków z NATO. Porozumienie zostało sfinalizowane w listopadzie 2003 r. w Neapolu. Zgodnie $\mathrm{z}$ jego postanowieniami UE ma posiadać niewielkie komórki planowania operacyjnego i ustanowić takie komórki przy SHAPE - Kwaterze Głównej Połączonych Sił Zbrojnych NATO w Europie ${ }^{50}$.

W 2004 r. Rada Europejska przyjęła nowy cel zasadniczy - Headline Goal $2010^{51}$. Należy stwierdzić, porównując z celem zasadniczym z 2003 r., że przyjęto podejście jakościowe, a nie ilościowe, przez koncepcję grup bojowych UE. Grupy te powinny składać się z 1500 żołnierzy, być gotowe do działania w ciągu 10 dni i być zdolne do

NATO Defence College's Research Paper No. 88, January 2013, s. 2; G.J. Kanis, M.R. van Ettinger, Operational Assessment of a NATO Response Force, http://streitcouncil.org/uploads/PDF/Operational\%20Assessment $\% 20$ of\%20NATO\%20Response\%20Force.pdf [data dostępu: 20.08.2016], s. 1-12.

${ }^{46}$ www.consilium.europa.eu/uedocs/cmsupload/03-11-11\%20berlin \%20plus\%20press $\% 20$ note\%20bl.pdf [data dostępu: 20.08.2016].

47 D.S. Yost, NATO and International Organizations, NATO Defense College, Research Division, Rome, September 2007, s. 77-78.

${ }^{48}$ F. Cameron, op. cit., s. 22.

${ }^{49}$ www.nato.int/cps/en/natohq/topics_49217.htm [data dostępu: 20.08.2016]. Zob. P. Sturm, NATO and the EU: Cooperation?, "European Security Review" 2010, Vol. 48, www.natowatch.org/ sites/default/files/2010_artrel_445_eu-nato-capabilities.pdf [data dostępu: 20.08.2016], s. 1-5.

${ }^{50}$ Zob. "Joint Paper by France, Germany and the United Kingdom" Naples, 29 November 2003, [w:] From Copenhagen to Brussel. European Defence: Core Documents, Vol. 4, compiled A. Missiroli, "Chaillot Papers" December 2003, No. 67, s. 283-284.

${ }^{51}$ www.consilium.europa.eu/uedocs/cmsUpload/2010\%20Headline\%20Goal.pdf [data dostępu: 20.08 .2016$]$. 
utrzymania się przez 30 dni z możliwością przedłużenia do 120 dni. Pełną zdolność operacyjną uzyskały w $2007 \mathrm{r}^{52}$ Równolegle rozwijano zdolności w sferze cywilnej. Wskazano cztery priorytetowe obszary: policję, rządy prawa, administrację i obronę cywilną. W związku z tym w 2004 r. szerzej określono cywilny cel zasadniczy, poszerzając zakres działań UE w obszarze reform sektora bezpieczeństwa, rozbrojenia, demobilizacji i reintegracji ${ }^{53}$. Rozwijano też współpracę instytucjonalną pomiędzy UE a NATO, głównie w oparciu o postanowienia Porozumień „Berlin plus”. Od 2005 r. w ramach SWUE działa Stała Grupa Łączności NATO, a od 2006 r. - komórka UE w SHAPE. Regularne kontakty utrzymuje ze sobą personel obu organizacji ${ }^{54}$.

Zgodnie z postanowieniami Traktatu z Lizbony z dnia 13 grudnia 2007 r. w myśl art. 42 ust. 1 i 3 Traktatu o UE - Wspólna Polityka Bezpieczeństwa i Obrony (dawna EPBiO) jest realizowana za pomocą środków dostarczonych przez państwa członkowskie UE. Oprócz wcześniej wymienionych organów (KPiB, KWUE, SWUE) w ramach Europejskiej Służby Działań Zewnętrznych za realizację WPBiO są odpowiedzialne Dyrekcja Zarządzania Kryzysowego i Planowania oraz Komórka Planowania i Prowadzenia Operacji Cywilnych (KPiPOC). Dyrekcja zajmuje się polityczno-strategicznym planowaniem oraz dokonuje analizy operacji wojskowych i misji cywilnych WPBiO, a KPiPOC odpowiada głównie za misje cywilne ${ }^{55}$. Należy zauważyć, że w Traktacie z Lizbony zawarto nieliczne odniesienia do relacji między UE a NATO. Terminem „NATO” posłużono się tylko dwukrotnie w Traktacie o UE w kontekście WPBiO w art. 42 ust. 2 i $7^{56}$. Można zatem stwierdzić, że Traktat ten w niewielkim stopniu wpłynął na relacje pomiędzy UE a NATO.

W 2010 r. została przedstawiona niemiecko-szwedzka inicjatywa Ghent, której celem jest zachowanie i wzmocnienie narodowych zdolności operacyjnych. Zakłada ona wzmocnienie przez państwa członkowskie ich interoperacyjności i zdolności rozmieszczenia. Głównym celem gromadzenia i dzielenia się (pooling and shering) jest większa dostępność zdolności operacyjnych państw członkowskich, by mogły być użyte przez UE lub NATO ${ }^{57}$.

52 www.consilium.europa.eu/uedocs/cms_data/docs/pressdata/en/esdp/91624.pdf [data dostępu: 20.08.2016]; A. Barcikowska, EU Battlegroups - Ready to Go?, "European Union Institute for Security Studies" 2013, No. 40, s. 1-4; A.I. Xavier, The EU's Battlegroup in Perspective: Addressing Present Challenges for Future Deployments, Austria Institute für Europa-und-Sicherheitspolitik, "Focus" 2013, No. 7, s. 1-4.

53 T. Tardy, The EU: Facing Non-Traditional Threats in a Globalized World, [w:] Great Powers and Strategic Stability in the $21^{\text {st }}$ Century: Competing Visions of World Order, ed. G.P. Herd, Routledge 2010, s. 179.

${ }^{54}$ N. Graeger, K.M. Haugevik, The EU's Performance with and within NATO: Assessing Objectives, Outcomes and Organisational Practices, "European Integration” 2011, Vol. 33, No. 6, s. 746.

55 Zob. P. Koutrakos, EU International Relations..., s. 454-455.

${ }_{56}$ N. Graeger, K.M. Haugevik, op. cit., s. 745.

${ }^{57}$ European Defence Agency, EDA's Pooling\&Shering, Fact Sheet, www.eda.europa.eu/docs/ default-source/eda-factsheets/final-p-s_30012013_factsheet_cs5_gris [data dostępu: 20.08.2016]. 
W lutym 2011 r. Sekretarz Generalny NATO A.F. Rasmussen przedstawił podobną koncepcję dotyczącą finansowania działań obronnych - tzw. inteligentną obronę (Smart Defence), przewidującą bardziej elastyczną współpracę przy zmniejszonych nakładach środków finansowych. Wspólne budowanie zdolności ma służyć gromadzeniu i dzieleniu środków, by państwa członkowskie NATO mogły uzyskać niezbędne zdolności ${ }^{58}$. Jednym z założeń tej koncepcji jest stworzenie strategicznej harmonii pomiędzy NATO a innymi podmiotami, w szczególności UE. Koncepcja inteligentnej obrony obejmuje trzy elementy: ustalenie priorytetów, współpracę i specjalizację $e^{59}$. W grudniu 2013 r., po raz pierwszy od wejścia w życie Traktatu z Lizbony, Rada Europejska przeprowadziła debatę dotyczącą problematyki bezpieczeństwa, którą poprzedziło spotkanie z Sekretarzem Generalnym NATO. W trakcie debaty określono niezbędne działania służące pogłębieniu współpracy, zaliczając do nich wzmocnienie skuteczności, obecności i wpływu WPBiO oraz wzrost rozwoju zdolności i wzmocnienie europejskiego przemysłu obronnego. Podkreślono, że rozwój WPBiO powinien odbywać się w sposób komplementarny w stosunku do działalności NATO, w poszanowaniu autonomii decyzyjnej i proceduralnej obu organizacji. Stwierdzono także, że WPBiO przyczyni się do wzmocnienia bezpieczeństwa obywateli Europy oraz pokoju i stabilności w państwach sąsiadujących z UE ${ }^{60}$. Kilka miesięcy później Rosja jednak dokonała agresji na Ukrainie. Okazało się wówczas, że UE nie była w stanie w odpowiedni sposób zareagować na jej działania ${ }^{61}$.

Wyróżnia się kilka faz kształtowania się współpracy pomiędzy UE a NATO, które pod względem czasowym zachodzą na siebie. Pierwszą fazę, od Traktatu z Maastricht, stanowi okres współzawodnictwa pomiędzy obiema organizacjami. Trwa ona nadal, chociaż zmianie uległy forma i charakter tej rywalizacji. W kolejnej fazie, określanej mianem formalizacji, zainicjowanej w 1999 r., skupiono się na wypracowaniu jasnych i skutecznych metod współpracy pomiędzy tymi

Zob. C. Mölling, Study: State of Play of the Implementation of EDA's Pooling and Sharing Initiatives and its Impact on the European Defence Industry, European Parliament, Policy Department, Directorate-General for External Policies, EP/EXPO/B/SEDE/FWC/2013-08/Lot6/03, June 2015 -PE 534.988, s. 10-21; Capability Development Plan, www.eda.europa.eu/what-we-do/eda-priorities/strategies/Capabilities [data dostępu: 20.08.2016].

${ }^{58}$ www.natolibguides.info/smartdefence [data dostępu: 20.08.2016]; J. Henius, J.L MacDonald, Smart Defence: A Critical Appraisal, NATO Defence College, NDC Forum Papers Series, Rome, March 2012, s. 4-47. Zob. C. Mölling, op. cit., s. 22-23.

59 J. Henius, J.L MacDonald, op. cit., s. 7; C. Mölling, op. cit., s. 22.

${ }^{60}$ European Council 19/20 December 2013, EUCO 217/13, pkt. 1-22. Zob. Press, Council Conclusions on Common Security and Defence Policy, Foreign Affairs (Defence) Council Meeting Brussels, 18 November 2014; Council Conclusions on CSDP, Brussels, 18 May 2015, 8947/15 CSDP/PSDC 278 COPS 149 CFSP/PESC 157 POLMIL 60 CIVCOM 84.

${ }^{61}$ C. Mölling, op. cit., s. 29. 
organizacjami. Formalizacja ta zainicjowała także kolejną fazę - impasu lub status quo, którą cechował rozłam zarówno wśród państw członkowskich NATO, jak i UE odnośnie do kwestii interwencji USA i wojsk koalicji w Iraku. Ponadto spór pomiędzy Turcją a Cyprem uniemożliwił wymianę tajnych informacji pomiędzy NATO a UE oraz udział Cypru w spotkaniach UE-NATO dotyczących strategicznej współpracy ${ }^{62}$. Ostatnią fazę można określić mianem „normalizacja przez deformalizację" wzajemnych stosunków, do której także przyczynił się impas w stosunkach Turcja - Cypr ${ }^{63}$.

\section{OPERACJE UE I NATO}

\section{Operacja Concordia}

W dniu 31 marca 2003 r. UE zainicjowała operację Concordia ${ }^{64}$ w byłej Jugosłowiańskiej Republice Macedonii (BJRM), która była zarówno pierwszą operacją militarną UE, jak i pierwszą operacją stwarzającą możliwość implementacji Porozumień „Berlin plus” ${ }^{\prime}$. Concordia zastąpiła operację NATO Allied Harmony, którą poprzedziły: Essenstial Harvest, Amber Fox. Zadaniem NATO było zapewnienie przestrzegania porozumienia z Ohrid, które zawarły władze BJRM z Albańczykami w celu zakończenia istniejącego pomiędzy nimi konfliktu ${ }^{66}$. Wysiłki społeczności międzynarodowej zostały wsparte rezolucją Rady Bezpieczeństwa $(\mathrm{RB})^{67}$. Operacja Concordia miała trwać sześć miesięcy, ale została przedłużona do 15 grudnia 2003 r. ${ }^{68}$ Podjęto ją na prośbę władz BJRM, a jej celem było utrzymanie stabilnego i bezpiecznego środowiska, by umożliwić władzom BJRM implementację porozumienia z Ohrid. Cechą charakterystyczną tej operacji było to, że zastąpiła operację NATO, korzystając z zasobów i zdolności Soju-

${ }^{62}$ M. Drent, From 'Effective' to 'Selective Multilateralism': the European Union's Relations with NATO, [w:] The EU and Effective Multilateralism: Internal and External Reform Practices, eds. E. Drieskens, L.G. van Schaik, Routledge 2014, s. 119-122; D. Keohane, ESDP ..., s. 127. D. Keohane pierwszą fazę datuje od 1999 do 2003 r., kolejna obejmuje lata 2003-2007, a ostatnia trwa od 2007 r. do dziś.

${ }_{63}$ M. Drent, op. cit., s. 119-124, 132.

${ }^{64}$ Council Joint Action 2003/92/CFSP (27 January 2003), OJ L 34/26, 11.02.2003.

${ }_{65}$ J.A. Koops, The European Union as an Integrative Power: Assessing the EU's 'Effective Multilateralism' Towards NATO and the United Nations, Institute for European Studies, Vrije Universiteit Brussel 2011, s. 292; D. Lynch, A. Missiroli, ESDP Operations, European Union Institute for Security Studies, www.peacepalacelibrary.nl/ebooks/files/09-dvl-am.pdf [data dostępu: 20.08.2016].

${ }^{66}$ P. Koutrakos, The EU Common Security and Defence Policy, Oxford 2013, DOI: http:// dx.doi.org/10.1093/acprof:oso/9780199692729.001.0001, s. 107.

${ }^{67} \mathrm{~S} / \mathrm{RES} / 1371$ (2001), 26 September 2001.

${ }^{68}$ Council Joint Action 2003/563/CFSP (29 July 2003), OJ L 190/20, 30.07.2003. 
szu zgodnie z zawartymi porozumieniami ${ }^{69}$. Zależność ta wynikała z charakteru Porozumień „Berlin plus”70. Dowódcą operacyjnym został Zastępca Naczelnego Dowódcy Połączonych Sił Zbrojnych NATO w Europie (D-SACEUR), natomiast kwatera operacyjna znajdowała się w Kwaterze Głównej Połączonych Sił Zbrojnych NATO w Europie, w Mons (SHAPE) ${ }^{71}$. Monitorowanie wykonania operacji powierzono KWUE, a KPiB sprawował polityczną kontrolę i strategiczne kierownictwo $^{72}$. Zgodnie z art. 10 wspólnego działania 2003/92/CFSP kontakty i spotkania przedstawicieli UE z NATO powinny odbywać się w trakcie przygotowania i prowadzenia operacji tak, by zapewnić transparentność, współpracę i konsultacje pomiędzy organizacjami. KPiB był zobowiązany do informowania Rady Północnoatlantyckiej o planowanym terminie zakończenia operacji przed przedłożeniem go Radzie. W art. 11 postanowiono także, że Wysoki Przedstawiciel UE ds. WPZiB może przekazywać tajne informacje NATO i zaangażowanym w operację państwom trzecim.

Operację Concordia należy postrzegać w nieco szerszym kontekście, tzn. woli zapewnienia przez UE stabilizacji w całym regionie ${ }^{73}$. Świadczyła ona także o tym, że UE jest gotowa do prowadzenia operacji wojskowych na niewielką skalę, a postanowienia Porozumień „Berlin plus” są przez nią implementowane ${ }^{74}$. Istotnym efektem tej operacji było też ustanowienie przez Radę w 2004 r. mechanizmu Athena ${ }^{75}$ polegającego na utworzeniu funduszu, z którego są pokrywane wspólne koszty operacji. Koszty są dzielone z uwzględnieniem kryterium dochodu narodowego brutto ${ }^{76}$. Należy podkreślić, że operacja Concordia oznaczała, że współpraca pomiędzy NATO i UE uzyskała praktyczny wymiar i stanowiła przygotowanie do kolejnej, bardziej złożonej operacji Althea ${ }^{77}$.

${ }^{69}$ P. Koutrakos, The EU Common Security..., s. 108; J. Varwick, J.A. Koops, The European Union and NATO: 'Shrewd Interorganizationalism' in the Making?, [w:] The European Union and International Organizations, ed. K.E. Jørgensen, Routledge 2009, s. 106.

${ }^{70}$ C. Egger, Being the Best at Winning the Peace. NATO and EU Rival Development of a Comprehensive Approach to Crisis Management, 2013, https://halshs.archives-ouvertes.fr/ halshs-00804164 [data dostępu: 20.08.2016], s. 19-20.

${ }^{71}$ J.A. Koops, op. cit., s. 297.

72 P. Koutrakos, The EU Common Security..., s. 108.

73 Zob. J.A. Koops, op. cit., s. 297-307.

74 A.P. Rodt, Taking Stock of EU Military Conflict Management, "Journal of Contemporary European Research" 2011, Vol. 7, No. 1, s. 44.

${ }^{75}$ Zob. Council Decision 2004/197/CFSP of 23 February 2004 establishing a mechanism to administer the financing of the common costs of European Union operations having military or defence implications, OJ L 63/68, 28.02.2004; Council Decision 2015/528/CFSP of 27 March 2015 establishing a mechanism to administer the financing of the common costs of European Union operations having military or defence implications (Athena) and repealing Decision 2011/871/CFSP, OJ L 84/39, 28.03.2015.

${ }^{76}$ K. Engberg, The EU and Military Operations: A Comparative Analysis, Routledge 2013, s. $53-54$.

77 J. Varwick, J.A. Koops, op cit., s. 106-107. 
15 grudnia 2003 r. ${ }^{78}$ operacja Concordia została zastąpiona operacją policyjną UE Proxima $^{79}$. Po podjęciu decyzji o uruchomieniu operacji wywiązała się dyskusja na temat jej znaczenia dla UE i jej roli w regionie. Grupa badawcza wskazała wiele nieprawidłowości w funkcjonowaniu systemu wymiaru sprawiedliwości, policji, ale nie określiła, jakie korzyści mogą wynikać z ewentualnej misji UE. W związku z tym dość szeroko ustalono zakres jej mandatu ${ }^{80}$. Główne cele operacji to wspieranie rozwoju skutecznej i profesjonalnej służby policyjnej, wzmocnienie rządów prawa ${ }^{81}$, budowa zaufania do policji w społeczności lokalnej oraz wzmocnienie współpracy z państwami sąsiednimi. Operację przedłużono na kolejny rok do 14 grudnia $2005 \mathrm{r}^{82}$

\section{Operacja Althea $^{83}$}

Była to druga, po Concordii, operacja UE na Bałkanach ${ }^{84}$. W latach 90. XX w. poszczególne republiki Socjalistycznej Federacyjnej Republiki Jugosławii ogłaszały niepodległość, w tym Bośnia. W związku z brutalnymi walkami na tle etnicznym NATO zdecydowało o interwencji militarnej w celu zakończenia konfliktu. W 1995 r. podpisano w Dayton ramowe porozumienie pokojowe ${ }^{85}$, które zakończyło wojnę. W tym samym roku NATO rozpoczęło operację Joint Endeavor i rozmieściło 60 tys. żołnierzy w ramach sił implementacyjnych (IFOR) ${ }^{86}$. $\mathrm{W}$ grudniu 1996 r. IFOR zastąpiły siły stabilizacyjne - SFOR, w liczbie 30 tys. $^{87}$, które podobnie jak IFOR miały stosować postanowienia Aneksu 1A dotyczące

${ }^{78}$ Council Joint Action 2003/681/CFSP of 29 September 2003, OJ L 249/66, 01.10.2003; Council Joint Action 2004/87/CFSP of 26 January 2004 amending Joint Action 2003/681/CFSP on the European Union Police Mission in the Former Yugoslav Republic of Macedonia (EUPOL Proxima), OJ L 21/31, 28.04.2004.

79 Zob. K. Engberg, op. cit., s. 53; I. Ioannides, EUPOL Proxima/EUPAT (Fyrom): The EU Police Mission (EUPOL Proxima) and European Union Police Advisory Team (EUPAT) in the Former Yugoslav Republic of Macedonia, [w:] European Security and Defence Policy..., s. 187-192; T. Palm, Normative Power and Military Means: The Case of the UE in FYR Macedonia, [w:] New Approaches to EU Foreign Policy, eds. M. Wilga, I.P. Karolewski, Routledge 2014, s. 155.

${ }^{80}$ C. Gourlay, The Politics of EU Civilian Interventions and the Strategic Deficit of the CSDP, Geneva Center for the Democratic Control of Armed Forces, Brussel-ISIS Europe, EU Crisis Management Papers, September 2011, with revised Chart, September 2012, s. 9-10.

${ }^{81}$ Zob. T. Palm, op. cit., s. 155-156.

${ }^{82}$ I. Ioannides, op. cit., s. 190.

${ }^{83}$ Council Joint Action 2004/570/CFSP of 12 July 2004 on the European Union military operation in Bosnia and Herzegovina, OJ L 252/10, 28.07.2004. Zob. S/RES/1551, 9 July 2004.

${ }^{84}$ P. Koutrakos, The EU Common Security..., s. 111.

${ }^{85}$ www.nato.int/ifor/gfa/gfa-home.htm [data dostępu: 20.08.2016].

${ }^{86}$ www.nato.int/ifor/ifor.htm [data dostępu: 20.08.2016].

87 www.nato.int/sfor [data dostępu: 20.08.2016]. 
wojskowych aspektów porozumienia pokojowego z Dayton ${ }^{88}$. Działania SFOR zostały zastąpione operacją UE Althea $^{89}$.

$\mathrm{Na}$ szczycie w Istambule w 2004 r. NATO podjęło decyzję o zakończeniu operacji w Bośni i Hercegowinie $(\mathrm{BiH})^{90}$. W związku z tym, że podczas wojny na Bałkanach UE nie podjęła skutecznych działań, lokalne elity i społeczeństwo postrzegały NATO i USA za bardziej wiarygodnych gwarantów bezpieczeństwa. W całej operacji kluczowe okazało się zatem, na mocy Porozumień „Berlin plus", korzystanie z zasobów i zdolności NATO, co znacznie wzmocniło wiarygodność UE ${ }^{91}$. Zgodnie z tymi Porozumieniami Dowódcą operacyjnym został D-SACEUR. Przedstawiał on raporty KWUE. KPiB sprawował strategiczne kierownictwo nad misją, a KWUE monitorował jej właściwe wykonanie ${ }^{92}$. Celem operacji było monitorowanie implementacji postanowień ramowego porozumienia pokojowego, co w praktyce polegało na patrolowaniu terenu i konfiskacie broni. W praktyce w pierwszej fazie operacji, która trwała od 2007 r., interwencja sił UE była ukierunkowana na zmianę stosunku ludności lokalnej wobec osób podejrzanych o zbrodnie wojenne. W drugiej fazie (w 2007 i 2012 r.) ograniczono liczebność jednostek UE i skoncentrowano je głównie w okolicach Sarajewa ${ }^{93}$. Obecnie UE zajmuje się budowaniem zdolności i szkoleniem sił zbrojnych BiH. W razie potrzeby istnieje możliwość wezwania tymczasowych sił rezerwowych w celu udzielenia natychmiastowego wsparcia organom wymiaru sprawiedliwości $\mathrm{BiH}^{94}$. Należy zauważyć, iż - inaczej niż w przypadku Concordii-współpraca partnerów operacji nie układała się dobrze. Francja, uznając, że NATO sprawowało nadmierną kontrolę podczas operacji Concordia, domagała się powołania dodatkowego dowódcy UE z siedzibą w regionalnym dowództwie NATO w Neapolu, czemu przeciwna była Wielka Brytania. W wyniku kompromisu powołano Specjalnego Przedstawiciela UE ${ }^{95}$.

Operacje Concordia i Althea świadczą o skutecznym zastosowaniu w terenie postanowień Porozumień „Berlin plus”, natomiast mniej pomyślnie przebiegała

${ }^{88}$ Stabilizations Force Transfer of Authority, 5 October 2004 (pdf), www.nato.int/sfor [data dostępu: 20.08.2016], s. 22-23.

${ }^{89}$ D. Keohane, EUFOR Althea (Bosnia and Hercegovina): The European Union Military Operation in Bosnia and Herzegovina (Althea), [w:] European Security and Defence Policy..., s. 212.

${ }^{90}$ www.nato.int/docu/update/2004/06-june/e0629f.htm [data dostępu: 20.08.2016].

91 J. Koops, op. cit., s. 342.

92 Zob. Council Joint Action 2004/570/CFSP, art. 2-4, 8.

93 P. Koutrakos, The EU Common Security..., s. 112. Zob. K. Engberg, op. cit., s. 54-56; J. Knauer, EUFOR Althea: Appraisal and Future Perspectives of the EU's Former Flagship Operation in Bosnia and Herzegovina, College of Europe, Department of EU International Relations and Diplomacy Studies, EU Diplomacy Paper 07/2011, s. 10-13.

94 Force Re-Structuring, www.euforbih.org/index.php?option=com_content\&view=article\&id $=2821$ [data dostępu: 20.08.2016].

${ }_{95}$ C. Egger, op. cit., s. 21. 
współpraca polityczna, ponieważ z jednej strony UE chciała korzystać z zasobów i zdolności NATO, a z drugiej eksponowała swoją autonomię ${ }^{96}$. Stopniowo powstawała sieć częstych i efektywnych kontaktów pomiędzy personelem wojskowym a jednostkami odpowiedzialnymi za strategiczne planowanie UE i NATO. Przyczyniła się ona do współdziałania tych organizacji w dziedzinie zarządzania kryzysowego $0^{97}$. W obu operacjach struktura dowodzenia była podobna. W operacji Althea istotną rolę odegrał Specjalny Przedstawiciel UE ${ }^{98}$, który udzielał wskazówek uczestnikom operacji i koordynował działania pomiędzy NATO a siedzibą UE w Sarajewie ${ }^{99}$. Althea odzwierciedlała sposób podejścia UE do kwestii zarządzania kryzysowego, które powinno mieć charakter wszechstronny, wielofunkcyjny, cywilno-wojskowy ${ }^{100}$.

\section{Misja EULEX Kosovo ${ }^{101}$}

Od zakończenia w 1999 r. operacji wojskowej Tymczasowa Misja Administracyjna ONZ administruje Kosowem (UNIMK). Jej mandat, o rozległym zakresie, określono w rezolucji RB 1244. Do zadań UNIMK, oprócz ustanowienia tymczasowej administracji cywilnej, pomocy w odbudowie infrastruktury i pomocy humanitarnej, należał podział zadań pomiędzy różne podmioty zaangażowane w proces pokojowy w Kosowie ${ }^{102}$. Od początku misji ONZ NATO odpowiadało za bezpieczeństwo Kosowa, a OBWE - za demokratyzację i budowę instytucji ${ }^{103}$.

EULEX Kosovo jest jedną z największych misji cywilnych UE, która została uruchomiona w trudnej sytuacji politycznej ${ }^{104}$. W styczniu 2006 r. UE wysłała misję fact-finding, by określić zakres przyszłej misji w dziedzinie rządów prawa.

96 J. Koops, op. cit., s. 342.

97 J. Varwick, J.A. Koops, op. cit., s. 107.

${ }_{98}$ Council Joint Action 2004/569/CFSP of 12 July 2004 on the mandate of the European Union Special Representative in Bosnia and Herzegovina and repealing Council Joint Action 2002/211/ CFSP, OJ L 252/7, 28.07.2004.

99 J. Koops, op. cit., s. 342-343.

${ }^{100}$ Ibidem, s. 345, 348.

${ }^{101}$ Council Joint Action 2008/124/CFSP of 4 February 2008 on the European Union Rule of Law Mission in Kosovo, EULEX KOSOVO, OJ 42/92, 16.02.2008. Zob. Council Decision 2014/685/CFSP of 29 September 2014 amending Joint Action 2008/124/CFSP on the European Union Rule of Law Mission in Kosovo, EULEX KOSOVO, OJ L 284/51, 30.09.2014.

${ }^{102}$ S/RES/1244, 10 June 1999. Zob. O. Dursun-Ozkanca, Does it Take Four to Tango? A Comparative Analysis of International Collaboration on Peacebuilding in Bosnia and Herzegovina and Kosovo, "Journal of Balkan and Near Eastern Studies" 2010, Vol. 12, No. 4, s. 443-444; M. Spernbauer, EU Peacebuilding in Kosovo and Afghanistan: Legality and Accountability, Martinus Nijhoff Publishers 2014, DOI: http://dx.doi.org/10.1163/9789004265714, s. 49-74.

${ }^{103}$ O. Dursun-Ozkanca, op. cit., s. 445.

${ }^{104}$ S. Blockmans, R.A. Wessel, The European Union and Crisis Management: Will the Lisbon Treaty Make the EU More Effective?, "Journal of Conflict and Security Law" 2009, Vol. 14, No. 2, s. 276. 
Zalecono powołanie przez UE jednostki planowania, która przygotowałaby misję. Zakładano, że na przełomie 2006 i 2007 r. UNMIK wycofa się, a RB upoważni UE do prowadzenia misji w Kosowie ${ }^{105}$. Uchwalenie takiej rezolucji przez RB było blokowane przez Rosję i Chiny. W związku z tym RB postanowiła dokonać rekonstrukcji w odniesieniu do cywilnej obecności UNMIK, zastępując niektóre jej elementy misją $E U L E X^{106}$. Uzgodniono dwa wspólne działania, na mocy których uruchomiono w lutym 2008 r. misję EULEX Kosovo i powołano Specjalnego Przedstawiciela UE w Kosowie. Pełną zdolność operacyjną misja EULEX Kosovo uzyskała w kwietniu 2009 r. ${ }^{107}$ Podstawowym jej zadaniem było wsparcie dla władz Kosowa w zakresie rządów prawa, wymiaru sprawiedliwości, tworzenia wieloetnicznych sił policyjnych i rozwoju służby celnej ${ }^{108}$. Realizacja celów misji napotkała na przeszkody w północnej części Kosowa, gdyż mniejszość serbska nie chciała współpracować z misją EULEX Kosovo, dlatego w tej części Kosowa mandat sprawowała UNIMK. Spowodowało to opóźnienie w osiągnięciu celów misji ${ }^{109}$. W związku $\mathrm{z}$ tymi trudnościami w terenie, w realizacji mandatu misji EULEX Kosovo istotna okazała się także współpraca z innymi podmiotami.

Zgodnie z postanowieniami rezolucji RB 1244 z 1999 r. NATO jest odpowiedzialne za ustanowienie i utrzymanie bezpieczeństwa w Kosowie. Niektóre zadania KFOR uległy zmianie, natomiast stały charakter miał obowiązek zapewnienia bezpiecznego środowiska. KFOR współpracuje w tym zakresie z ONZ, UE i innymi podmiotami ${ }^{110}$. W związku z tym, że z przyczyn politycznych trudno było osiągnąć porozumienie, w wielu obszarach współpraca ta odbywa się przez nieformalne kontakty, np. dowódców misji, szefów personelu ${ }^{111}$. Zawarto także porozumienia o charakterze technicznym, które przyczyniły się do usprawnienia współpracy w terenie ${ }^{112}$. Dotyczyły one reagowania na zamieszki, wsparcia wojskowego dla operacji cywilnych, wymiany informacji. W odniesieniu

${ }^{105}$ G. Grevi, EULEX Kosovo: The EU Rule-of-Law Mission in Kosovo (EULEX Kosovo), [w:] European Security and Defence Policy..., s. 356; M. Spernbauer, EULEX Kosovo: The Difficult Deployment and Challenging Implementation of the Most Comprehensive Civilian EU Operation to Date, "German Law Journal" 2010, Vol. 11, No. 8, s. 778.

${ }^{106}$ S. Blockmans, R.A. Wessel, op. cit., s. 277.

${ }^{107}$ Council Joint Action 2008/123/CFSP of 4 February 2008 appointing a European Union Special Representative in Kosovo, OJ L 42/88, 16.02.2008.

${ }^{108}$ N. Graeger, J. Tood, Still a "Strategic" EU-NATO Partnership? Bridging Governance Challenges through Practical Cooperation, "PISM Policy Paper" 2015, No. 21 (123), s. 2.

${ }^{109}$ O. Dursun-Ozkanca, op. cit., s. 449.

${ }^{110}$ www.aco.nato.int/kfor/about-us/natos-role-in-kosovo.aspx [data dostępu: 20.08.2016].

${ }^{111}$ Szerzej: N. Graeger, Security. EU-NATO Relations: Informal Cooperation as a Relations: Informal Cooperation as a Common Lifestyle, [w:] The European Union with(in) International Organisations: Commitment, Consistency, and Effects Across Time, ed. A. Orsini, Ashgate 2014, s. 157-180. Zob. P. Sturm, op. cit., s. 3.

${ }^{112}$ S.J. Smith, EU-NATO Cooperation: A Case of Institutional Fatigue?, "European Security" 2011, Vol. 20, No. 2, DOI: http://dx.doi.org/10.1080/09662839.2011.557771, s. 255. 
do reagowania na zamieszki przyjęto zasadę kaskadowej odpowiedzialności za bezpieczeństwo, tzn. w pierwszej kolejności reaguje lokalna policja, następnie EULEX Specjalna Jednostka Policji, a na końcu KFOR ${ }^{113}$. Jest to przykład spójnej polityki, zakładającej udział poszczególnych uczestników, której skuteczność zależy od współpracy trzech podmiotów. Podobnie jest w przypadku kontroli granic $^{114}$. W praktyce zdarzało się, że w pierwszej kolejności reagował KFOR ${ }^{115}$, co wywołało uzasadnioną krytykę, gdyż militarne zaangażowanie w misję cywilną może doprowadzić do eskalacji konfliktu ${ }^{116}$. Porozumienia techniczne stworzyły również możliwość współpracy pomiędzy ekspertami z Turcji i Cypru, uczestniczącymi w misji pomimo istniejącego sporu politycznego pomiędzy państwami, z których pochodzą ${ }^{117}$.

UE, NATO i OBWE współpracują także w szkoleniu kosowskich policjantów ${ }^{118}$. KFOR współpracuje $\mathrm{z}$ misją EULEX w zakresie egzekwowania prawa i walki z przestępczością zorganizowaną. W kwietniu 2013 r. Belgrad i Prisztina, dzięki staraniom UE, podpisały Pierwsze porozumienie dotyczące zasad rządzących normalizacją wzajemnych stosunków, a plan dotyczący implementacji jego postanowień przyjęto w maju 2013 r. Obie strony, w celu zapewnienia realizacji porozumienia, prowadzą dialog na wysokim szczeblu. NATO udzieliło pełnego wparcia tym działaniom ${ }^{119}$. W lipcu 2013 r. NATO i UE podpisały dokument Wspólnej Procedury Operacyjnej, którego celem jest usprawnienie współpracy przez mianowanie pełnoetatowych oficerów łącznikowych ${ }^{120}$.

UE i NATO, działając w Kosowie, wypełniały różne zadania i nie uzgodniły - w drodze formalnego porozumienia - zasad współpracy. Gwarantem bezpieczeństwa misji pozostaje NATO ${ }^{121}$. Dzięki zaangażowaniu UE, NATO i OBWE stan bezpieczeństwa w Kosowie uległ znacznej poprawie ${ }^{122}$, co spowodowało też zmiany w strukturze i zadaniach KFOR. W Kosowie obecnie znajdują się dwie Wielonarodowe Grupy Bojowe, wielkości batalionu, złożone z licznych wysoko mobilnych, szybko przemieszczających się kompanii, dlatego niezbędne było

${ }^{113}$ M. Spernbauer, EULEX Kosovo..., s. 799.

${ }^{114} \mathrm{M}$. Brosing, The Interplay of International Institutions in Kosovo between Convergence, Confusion and Niche Capabilities, "European Security" 2011, Vol. 20, No. 2, DOI: http://dx.doi.or g/10.1080/09662839.2011.564614, s. 196-197.

${ }^{115}$ N. Graeger, J. Tood, op. cit., s. 3.

${ }^{116}$ M. Brosing, op. cit., s. 196.

${ }^{117}$ N. Gaeger, J. Tood, op. cit., s. 3; S.J. Smith, op. cit., s. 255.

${ }^{118}$ O. Dursun-Ozkanca, op. cit., s. 450.

${ }^{119}$ Zob. Republik of Serbia Government, Office for Kosovo and Metohija, Progress Report on the Dialogue between Belgrade and Priština, April 2015; V. Musliu, S. Geci, Deconstructing and Defining EULEX, "Central European Journal of International and Security" 2014, Vol. 8, No. 1, s. 70.

${ }^{120}$ www.eulex-kosovo.eu/en/news/000443.php [data dostępu: 20.08.2016].

${ }^{121}$ S.J. Smith, op. cit., s. 245, 253, 255.

${ }^{122}$ M. Brosing, op. cit., s. 199. 
znalezienie nowego obszaru działań. KFOR zaangażował się w powołanie Kosowskich Sił Bezpieczeństwa (KSF) i w stworzenie cywilnej struktury nadzorującej KSF. W celu udzielenia dalszego wsparcia KSF NATO powołało, niezależną od KFOR, Grupę łącznikową i doradczą (NLAT) ${ }^{123}$. Powołanie przez NATO KSF, które miały pełnić głównie funkcje o charakterze cywilnym (np. udzielać pomocy władzom w przypadku katastrof naturalnych) wzbudziło obawy. Utworzenie organizacji paramilitarnej może doprowadzić do remilitaryzacji struktur cywilnych. Wydaje się, że podejmując działania o charakterze cywilno-wojskowym ${ }^{124}$, NATO chciało potwierdzić potrzebę swojej obecności w Kosowie ${ }^{125}$.

\section{Operacja NAVFOR Atalanta}

NAVFOR Atalanta ${ }^{126}$ stanowi pierwszą operację morską UE, która miała istotny wpływ na rozwój relacji pomiędzy UE a NATO w dziedzinie bezpieczeństwa morskiego, chociaż działania były prowadzone odrębnie przez obie organizacje, poza Porozumieniami „Berlin plus” ${ }^{127}$. Operacja ta służyła także ochronie podstawowych interesów państw członkowskich UE - handlu morskiego i wolności mórz, bowiem rocznie ponad 15\% wartości towarów handlu światowego jest przeprawiane przez Kanał Kiloński i Zatokę Adeńską ${ }^{128}$. Ponadto bezpieczeństwo energetyczne UE zależy od transportu i infrastruktury morskiej, dlatego region ten ma znaczenie nie tylko dla UE, ale i dla dużych rynków światowych - Chin, Indii, USA ${ }^{129}$. W związku z tym we wrześniu $2008 \mathrm{r}$. utworzono jednostkę koordynacyjną w Brukseli w celu wspierania działań wywiadowczych i ochronnych prowadzonych u wybrzeży Somalii przez niektóre państwa członkowskie UE ${ }^{130}$.

${ }^{123}$ www.nato.int/cps/en/natolive/topics_48818.htm [data dostępu: 20.08.2016].

${ }^{124}$ Zob. NATO Military Policy on Civil-Military Co-operation, MC 411/1, www.nato.int/ims/ docu/mc411-1-e.htm [data dostępu: 20.08.2016].

${ }^{125}$ M. Brosing, op. cit., s. 199-200.

${ }^{126}$ Council Joint Action 2008/851/CFSP of 10 November 2008 on a European Union military operation to contribute to the deterrence, prevention and repression of acts of piracy and armed robbery off the Somali coast, OJ L 301/33, 12.11.2008; Council Decision 2014/827/CFSP of 21 November 2014 amending Joint Action 2008/851/CFSP on a European Union military operation to contribute to the deterrence, prevention and repression of acts of piracy and armed robbery off the Somali coast, OJ L 335/19, 22.11.2014.

127 J. Koops, op. cit., s. 382.

${ }^{128}$ B. Germond, The Maritime Dimension of European Security: Seapower and the European Union, Palgrave Macmilla 2015, DOI: http://dx.doi.org/10.1057/9781137017819, s. 107.

${ }^{129}$ D. Helly, EU NAVFOR Somalia: The EU Military Operation Atalanta, [w:] European Security and Defence Policy..., s. 393-394.

${ }^{130}$ J. Larik, Europe's Fight Against Piracy: From the Barbary Coast to Operation Atalanta, Fondation Pierre du Bois, Papiers d'actualité/Current Affairs in Perspective, Mai 2013, No. 4, s. 2. 
NAVFOR Atalanta uruchomiono w grudniu 2008 r., by zapobiegać i tłumić akty piractwa i rozbójnictwa morskiego u wybrzeży Somalii ${ }^{131}$. Misja stanowiła także odpowiedź na wezwania RB dotyczące przeciwdziałania zagrożeniom związanym $\mathrm{z}$ aktami piractwa na wodach terytorialnych Somalii ${ }^{132}$ i wpisywała się w inicjatywy różnych państw, które w zagrożony rejon kierowały okręty marynarki wojennej. Podobne działania podjęło NATO, uruchamiając operację Allied Provider i wysyłając okręty sił morskich wysokiej gotowości, stanowiące część sił odpowiedzi NATO $(\mathrm{NRF})^{133}$. W marcu 2009 r. NATO zastąpiło operację Allied Provider operacją Allied Protector, a od sierpnia 2009 r. - operacją Ocean Shield. Podobnie jak poprzednie działania NATO, wspiera ona wysiłki społeczności międzynarodowej na rzecz budowy bezpieczeństwa żeglugi w regionie oraz współpracuje z UE, Połączonymi Siłami 151 (Combined Task Force - CTF 151) i państwami działającymi indywidualnie w regionie (np. Japonią, Chinami, Koreą Południową) $)^{134}$. Operacja NAVFOR Atalanta miała dwa podstawowe cele: zapewnienie bezpieczeństwa transportu żywności do Somalii oraz ochronę statków handlowych z państw członkowskich UE ${ }^{135}$. W marcu 2012 r. poszerzono jej obszar działania na wody wewnętrzne i terytorium lądowe Somalii, zwiększając skuteczność wysiłków na rzecz zwalczania aktów piractwa ${ }^{136}$. Podobnie jak w poprzednich operacjach, KPiB sprawował polityczną kontrolę i strategiczne kierownictwo nad misją, a KWUE monitorował wykonanie operacji. Kwatera misji znajduje się w Northwood w Wielkiej Brytanii, podobnie jak kwatera operacyjna NATO.

W kontekście operacji NAVFOR Atalanta trudno jest postrzegać UE jako samodzielny podmiot działań w dziedzinie bezpieczeństwa. Dla państw członkowskich stanowi jedną z kilku platform służących do realizowania własnych interesów na arenie międzynarodowej, poza WPBiO. Nawet zbieżność interesów państw członkowskich UE, uzasadniająca uczestnictwo w operacji NAVFOR Ata-

${ }^{131}$ European Union, European Security and Defence Policy, EU Naval Operation against Piracy (EU NAVFOR Somalia - Operation ATALANTA), www.iflos.org/media/34138/090422-factsheet_eu_navfor_somalia-version6_en.pdf [data dostępu: 20.08.2016], s. 1 .

${ }_{132}$ Zob. S/RES/1814, 15 May 2008; S/RES/1816, 2 June 2008; S/RES/1838, 7 October 2008; S/RES/1846, 2 December 2008; S/RES/1918 27, April 2010; B. Germond, M.E. Smith, Re-Thinking European Security Interests and the ESDP: Explaining the EUs Anti-Piracy Operation, "Contemporary Security Policy" 2009, Vol. 30, No. 3, DOI: http://dx.doi.org/10.1080/13523260903327741, s. 582; J.A. Roach, Countering Piracy off Somalia: International Law and International Institutions, "American Journal of International Law" 2010, Vol. 104, No. 3, s. 400-401.

${ }^{133}$ B. Germond, M.E. Smith, op. cit., s. 582. Zob. www.aco.nato.int/page13974522.aspx [data dostępu: 20.08.2016].

${ }^{134}$ Zob. www.nato.int/cps/en/natolive/topics_48815.htm\#Protector [data dostępu: 20.08.2016].

${ }^{135}$ B. Germond, op. cit., s. 107.

${ }^{136}$ Council Decision 2012/174/CFSP of 23 March amending Joint Action 2008/851/CFSP on a European Union military operation to contribute to the deterrence, prevention and repression of acts of piracy and armed robbery off the Somali coast, OJ L 89/69, 27.03.2012. 
lanta, nie stanowiła dla niektórych z nich przeszkody, by równocześnie angażować się w misje prowadzone np. przez $\mathrm{NATO}^{137}$. Ponadto operacja ta dowodzi, że WPBiO może zmierzać nie tylko do zapewnienia stabilności i pomocy humanitarnej, ale także przyczyniać się do ochrony interesów UE i jej państw członkowskich. NAVFOR Atalanta wykazała, że WPBiO może służyć jako środek do realizacji - szeroko zakreślonych - celów geopolitycznych UE, wykraczających poza zewnętrzne granice UE i państw sąsiednich ${ }^{138}$.

O znacznie poszerzonym zakresie działania UE w sprawach bezpieczeństwa świadczy też uruchomiona w 2012 r. operacja EUCAP Nestor ${ }^{139}$, której celem była budowa zdolności służących podniesieniu bezpieczeństwa w Rogu Afryki i na Zachodnim Oceanie Indyjskim, przez aktorów regionalnych, obejmująca kwestie bezpieczeństwa morskiego, zwalczania piractwa i wzmocnienia wymiaru sprawiedliwości przy ściganiu przestępstw popełnionych na morzu ${ }^{140}$. Podobnie było w przypadku uruchomionej w 2013 r. misji EUBAM w Libii, której zadaniem było wspieranie władz w wysiłkach na rzecz efektywnej ochrony granic ${ }^{141}$, i rozpoczętej w czerwcu 2015 r. operacji wojskowej EUNAVFOR MED ${ }^{142}$, której celem jest rozpoznanie i schwytanie statków oraz zajęcie środków ułatwiających przemyt migrantów i handel ludźmi w południowo-centralnej części Morza Śródziemnego. Od 7 października 2015 r. EUNAVFOR MED operacją Sophia zainicjowało drugą fazę tej operacji, w trakcie której na morzu otwartym będą dokonywane wejścia na pokład, rewizje, zajęcia i zawrócenia statku w przypadku podejrzenia o używanie go do przemytu migrantów lub handlu ludźmi. Podstawowym celem operacji jest zapobieganie tragediom na Morzu Śródziemnym oraz zniszczenie siatki przemytników migrantów i handlarzy ludźmi ${ }^{143}$.

Efektem doświadczeń wyniesionych z operacji NAVFOR Atalanta było także przyjęcie w czerwcu 2014 r. Strategii Bezpieczeństwa Morskiego (SBM),

${ }^{137}$ J. Larik, op. cit., s. 4-5.

${ }^{138}$ B. Germond, M.E. Smith, op. cit., s. 587-588.

${ }^{139}$ Council Decision 2012/389/CFSP of 16 July 2012 on the European Union Mission on Regional Maritime Capacity Building in the Horn of Africa (EUCAP NESTOR), OJ L 187/40, 17.07.2012.

${ }^{140}$ B. Germond, op. cit., s. 108.

${ }^{141}$ Council Decision 2013/233/CFSP of 22 May 2013 on the European Union Integrated Border Management Assistance Mission in Libya (EUBAM Libya), OJ L 138/15, 24.05.2013; Council Decision (CFSP) 2015/800 of 21 May 2015 amending and extending Decision 2013/233/CFSP on the European Union Integrated Border Management Assistance Mission in Libya (EUBAM Libya), OJ L 127/22, 22.05.2015.

${ }^{142}$ Council Decision (CFSP) 2015/972 of 22 June 2015 launching the European Union military operation in the southern Central Mediterranean (EUNAVFOR MED), OJ L 157/51, 23.06.2015.

${ }^{143}$ Factsheet on EUNAVFOR MED Mission, European Union Naval Force - Mediterranean Operation Sophia, http://eeas.europa.eu/csdp/missions-and-operations/eunavfor-med/index_en.htm [data dostępu: 20.08.2016]. 
która odnosi się zarówno do wewnętrznych, jak i zewnętrznych aspektów bezpieczeństwa morskiego ${ }^{144}$ oraz stanowi pierwszy krok w kierunku opracowania nowej globalnej strategii bezpieczeństwa UE ${ }^{145}$. Dokument ten stanowi najbardziej zintegrowaną i kompleksową strategię bezpieczeństwa UE. Jest on wzorowany na Europejskiej Strategii Bezpieczeństwa ${ }^{146}$ i Wewnętrznej Strategii Bezpieczeństwa ${ }^{147}$, a zatem uwzględnia czynniki zewnętrzne i wewnętrzne. Do głównych zasad zaliczono morski multilateralizm, tzn. podkreślono znaczenie współpracy i jej koordynacji ze wszystkimi podmiotami i partnerami międzynarodowymi, w tym NATO i ONZ, w dziedzinie bezpieczeństwa morskiego. Strategiczne interesy bezpieczeństwa morskiego UE i państw członkowskich obejmują: zachowanie pokoju, pokojowe regulowanie sporów morskich, zapobieganie konfliktom i wzmocnienie bezpieczeństwa międzynarodowego przez współpracę z innymi podmiotami. W kontekście zarządzania kryzysowego działania UE i NATO na morzu powinny wzajemnie się uzupełniać i być skoordynowane ${ }^{148}$.

${ }^{144}$ European Union Maritime Security Strategy [EUMSS], 11205/14, adopted by the General Affairs Council on 24 June 2014.

${ }^{145}$ Zgodnie z konkluzjami z dnia 26 czerwca 2015 r. Rada Europejska upoważniła Wysoką Przedstawiciel Unii ds. Zagranicznych i Polityki Bezpieczeństwa - F. Mogherini - do opracowania, we współpracy z państwami członkowskimi, w ciągu roku Globalnej strategii UE w zakresie polityki zagranicznej i bezpieczeństwa. W czerwcu 2016 r. przedstawiono nową Globalną strategię UE - Shared Vision, Common Action: A Stronger Euurope, w której podkreślono współzależność pomiędzy bezpieczeństwem wewnętrznym a zewnętrznym. Ponadto UE zobowiązała się do zapewnienia pokoju i bezpieczeństwa na obszarze UE. Wskazano także pięć priorytetów w zakresie działań zewnętrznych UE, w ramach których UE ma przyczynić się do wzmocnienia europejskiego bezpieczeństwa zbiorowego przez ścisłą współpracę z partnerami UE, w tym NATO. Stwierdzono, iż w zakresie europejskiego bezpieczeństwa i obrony UE powinna podjąć działania pozwalające na prowadzenie przez nią nie tylko akcji autonomicznych akcji, ale także we współpracy z NATO. Ponadto w celu zapewnienia bezpieczeństwa cybernetycznego stwierdzono potrzebę wzmocnienia współpracy ze Stanami Zjednoczonymi i NATO. Za konieczne uznano również pogłębienie współpracy pomiędzy państwami członkowskimi UE. Wyrażono wolę współpracy oraz koordynacji budowy zdolności z innymi podmiotami, w tym NATO i ONZ. UE zobowiązała się też do pogłębienia współdziałania z NATO przez skoordynowany rozwój zdolności obronnych, wspólne ćwiczenia, wspólne działania prowadzone w celu budowy własnych zdolności partnerów UE i NATO, zwalczenie hybrydowych i cyberzagrożeń oraz wzmocnienie bezpieczeństwa morskiego. W strategii wskazano również środki służące do osiągnięcia założonych celów. Szerzej: https://europa.eu/globalstrategy/en [data dostępu: 20.08.2016].

${ }^{146}$ www.eeas.europa.eu/csdp/about-csdp/european-security-strategy [data dostępu: 20.08.2016].

${ }^{147}$ Internal Security Strategy for the European Union: Towards a European Security Model, 5842/2/10 REV 2 JAI 90, agreed by the Council on 25 March 2010. Zob. Draft Council Conclusions on the Renewed European Union Internal Security Strategy 2015-2020, Brussels, 10 June 2015, 9798/15 JAI 442 COSI 67.

${ }^{148}$ EUMSS, Principles and Objectives III (d); Maritime Security Interests IV (b); Strengthening the EU Response VI (1). Zob. L. Landman, The EU Maritime Security Strategy Promoting or Absorbing European Defence Cooperation?, Clingendael Policy Brief, April 2015, s. 1-12. 
W grudniu 2014 r. Rada przyjęła Plan Działania w celu implementacji postanowień $\mathrm{SBM}^{149}$. Ze względu na zaangażowanie $\mathrm{w}$ zwalczanie piractwa $\mathrm{w}$ regionie znacznej liczby państw niezbędna okazała się koordynacja działań w drodze zawieranych ad hoc porozumień. Regularnie odbywały się spotkania na morzu dowódców flot oraz w kwaterze operacyjnej w Northwood. Powołano Grupę Kontaktową ds. Piractwa u wybrzeży Somalii, której UE i NATO są aktywnymi członkami ${ }^{150}$. W ramach SHADE ${ }^{151}$ w Bahrajnie odbywają się spotkania mające na celu koordynację działań różnych jednostek uczestniczących w zwalczaniu piractwa. W systemie rotacyjnym spotkaniom tym współprzewodniczą: NATO, NAVFOR Atalanta, CTF. W trakcie operacji NAVFOR Atalanta ustanowiono systemy służące do komunikacji pomiędzy siłami zaangażowanymi w regionie. Po pierwsze, utworzono Centrum Bezpieczeństwa Morskiego - Róg Afryki (Maritime Security Centre - Horn of Africa - MSCHOA) ${ }^{152}$, które przez całą dobę monitoruje statki przepływające przez Zatokę Adeńską. Po drugie, ustanowiono MERCURY - zabezpieczoną platformę internetową służącą do wymiany informacji w czasie rzeczywistym pomiędzy flotami, a także Common Operating Picture - pokazujący statki handlowe przepływające przez Zatokę Adeńską. Wielonarodową współpracę ułatwiają również powietrzne patrole (Maritime Patrol Aircraft). Usprawnienia w komunikacji okazały się pomocne w dialogu z Chinami i Rosją $a^{153}$.

Operacja NAVFOR Atalanta dowodzi, że zarówno UE, jak i NATO wzajemnie uzupełniają się w dziedzinie bezpieczeństwa morskiego i wywiadu. UE posiada doświadczenie w takich dziedzinach, jak bezpieczeństwo morskie, ochrona rybołówstwa, ochrona środowiska morskiego. Poza tym UE uchwaliła szereg aktów prawnych dotyczących np. bezpieczeństwa portów i żeglugi ${ }^{154}$. NATO także angażuje się w różne działania na rzecz utrzymania bezpieczeństwa morskiego (np. operacja na Morzu Śródziemnym Activ Endeavour ${ }^{155}$, Ocean Shield ${ }^{156}$ w Zatoce Adeńskiej i w Rogu Afryki).

${ }^{149}$ European Union Maritime Security Strategy EUMSS - Action Plan, 16 December 2014, $17002 / 14$.

${ }^{150}$ M. Drent, op. cit., s. 123.

${ }^{151}$ Shared Awareness and Deconfliction - powołany w 2008 r. cykl spotkań służących koordynacji i unikaniu sytuacji konfliktowych pomiędzy państwami, koalicjami zaangażowanymi w zwalczanie piractwa w Zatoce Adeńskiej i Zachodnim Oceanie Indyjskim. Tekst z: http://oceansbeyondpiracy.org/ matrix/shared-awareness-and-deconfliction-shade [data dostępu: 20.08.2016]. Spotkania takie odbywają się także w ramach EUNAVFOR MED: operacja Sophia, Press release 04/15, First Shared Awareness and De-confliction (SHADE) meeting for the Mediterranean Sea, Rome, November 26 2015, http://eeas. europa.eu/csdp/missions-and-operations/eunavfor-med/index_en.htm [data dostępu: 20.08.2016].

${ }^{152}$ www.mschoa.org/on-shore/about-us [data dostępu: 20.08.2016].

${ }^{153}$ D. Helly, op. cit., s. 399.

${ }^{154}$ B. Germond, op. cit., s. 123.

${ }^{155}$ Szerzej: www.nato.int/cps/en/natolive/topics_7932.htm [data dostępu: 20.08.2016].

${ }^{156}$ Szerzej: www.mc.nato.int/ops/Pages/OOS.aspx [data dostępu: 20.08.2016]. 
Należy podkreślić, że operacje UE i NATO były prowadzone na tym samym obszarze i posiadały zbliżone cele, ale nie było pomiędzy nimi więzi o charakterze formalnym. Istniały odrębne stanowiska dowodzenia, o zróżnicowanej strukturze. Pomimo impasu politycznego personelowi obu organizacji udało się przezwyciężyć ograniczenia polityczne i w sposób nieformalny wypracować mechanizm pozwalający na instytucjonalizację i usprawnienie współpracy, czego przykładem są NAVCO, SHADE, MERCURY. Warte podkreślenia jest także to, że prawdopodobnie po raz pierwszy wzajemne stosunki pomiędzy UE i NATO można określić mianem nie współzawodnictwa, lecz współpracy. Wydaje się, że udział obu organizacji w działaniach na rzecz zwalczania piractwa pozwolił na tak liczny udział państw trzecich, które miały możliwość dokonania wyboru podmiotu do współpracy ${ }^{157}$.

\section{UWAGI KOŃCOWE}

W oficjalnych dokumentach często podkreśla się, że UE i NATO są wyjątkowymi partnerami. Obie organizacje łączą wspólne wartości, poza tym znaczna część państw członkowskich NATO należy do UE. NATO i UE mogą, a nawet powinny, wzajemnie się wspierać i uzupełniać w utrzymywaniu międzynarodowego pokoju i bezpieczeństwa ${ }^{158}$.

W okresie zimnej wojny NATO i Wspólnoty Europejskie nie utrzymywały ze sobą kontaktów, skupiając się na odmiennych zadaniach. UZE odegrała niewielką rolę, ograniczając się do powojennej kontroli zbrojeń w Europie Zachodniej. Sytuacja międzynarodowa w początkach lat 90 . XX w. wymagała ze strony państw europejskich większego zaangażowania $\mathrm{w}$ celu zapewnienia własnego bezpieczeństwa. Istotną rolę w tym procesie odegrały dwa czynniki: zakończenie zimnej wojny i określenie nowej roli NATO oraz niezdolność UE do zapobieżenia konfliktowi na Bałkanach i jego szybkiego zakończenia ${ }^{159}$. W latach 90. XX w. świat wciąż wydawał się zdominowany przez Zachód. Stany Zjednoczone traktowano jako hegemona i filar porządku międzynarodowego, a NATO gwarantowało to niezakłócone przywództwo ${ }^{160}$. W Strategii Bezpieczeństwa Narodowego

${ }^{157}$ Szerzej: C. Gebhard, S.J. Smith, The Two Faces of EU-NATO Cooperation: Counter-Piracy Operations off the Somali Coast, "Cooperation and Conflict" 2015, Vol. 50, No. 1, DOI: http:// dx.doi.org/10.1177/0010836714532917, s. 107-127.

${ }^{158}$ Zob. np. Active Engagement, Modern Defence, Strategic Concept for the Defence and Security of the Members of the North Atlantic Treaty Organization Adopted by Heads of State and Government at the NATO Summit in Lisbon 19-20 November 2010 (Strategic Concept 2010), pkt 32; EU-NATO, EUISS Yearbook of European Security 2015, s. 54.

${ }^{159}$ C. Egger, op. cit., s. 13-14.

${ }^{160}$ A. de Vasconcelos, Introduction - 2020: Defence Beyond the Transatlantic Paradigm, [w:] What Ambitions for European Defence in 2020?, ed. A. de Vasconcelos, European Union Institute for Security Studies, Report No. 8, November 2010, s. 8. 
z 2015 r. ${ }^{161}$ Stany Zjednoczone wyraźnie wskazały, że wciąż chcą być primus inter pares $\mathrm{w}$ dziedzinie militarnej, politycznej i gospodarczej. Potrzebują jednak do współpracy partnera z odpowiednimi zdolnościami. W kontekście zarządzania kryzysowego USA będą angażowały się w określone misje i nie będą się ograniczać tylko do obszaru Europy ${ }^{162}$.

Zaprezentowane operacje świadczą o tym, iż w przypadku, gdy NATO, ONZ lub OBWE zmagają się z pewnymi trudnościami, UE wykazuje się pewnymi zdolnościami w dziedzinie zarządzania kryzysowego. Możliwa jest zatem synchronizacja różnych instrumentów z dziedziny europejskiej polityki zagranicznej, a także prowadzenie autonomicznych operacji, nawet w przypadku braku wsparcia USA. Operacje te stanowią swoistą wartość dodaną UE w dziedzinie bezpieczeństwa międzynarodowego ${ }^{163}$. Należy jednak zaznaczyć, że UE dotychczas nie prowadziła operacji długoterminowych, w niestabilnym środowisku, ponieważ jej operacje były ograniczone przedmiotowo i temporalnie. Nie sprawdzono zatem rzeczywistych zdolności UE w tym zakresie ${ }^{164}$.

Istotną cechą prowadzonych przez UE operacji jest również udział w nich państw trzecich, które mogą uczestniczyć we wspólnych działaniach na rzecz utrzymania międzynarodowego pokoju i bezpieczeństwa. Wspólne doświadczenia wynikające z operacji Concordia i Althea, prowadzonych w ramach Porozumień „Berlin plus”, przyczyniły się do uwspólnotowienia zarządzania kryzysowego UE w kontekście efektywnego multilateralizmu ${ }^{165}$ UE-NATO i UE-ONZ ${ }^{166}$. UE jest nie tylko zdolna do prowadzenia operacji wojskowych, ale też dyskusji politycznych na najwyższych szczeblach ${ }^{167}$.

W kontekście operacji EULEX Kosovo można stwierdzić, że łatwiej jest UE rozmieścić jednostki na określonym terytorium, niż ustalić wspólne stanowisko. Oznacza to, że większy postęp UE odnotowuje w dziedzinie bezpieczeństwa niż w obszarze

${ }^{161}$ www.whitehouse.gov/sites/default/files/docs/2015_national_security_strategy.pdf [data dostępu: 20.08.2016], s. 23-28.

162 J. Coelmont, CSDP: There is Something There that Was Not Before, [w:] The Common Security and Defence Policy: Nationals Perspectives, ed. D. Fiott, Egmont-Royal Institute for International Relations, Egmont Papers, Brussels, May 2015, s. 109-110.

${ }^{163}$ Zob. A. Mattellaer, J. Coelmont, Modern European Operations: From Phoney Wars to Sickle Cuts, [w:] The State of Defence in Europe: State of Emergency?, eds. S. Biscop, D. Fiott, Egmont - Royal Institute for International Relations, Egmont Papers No. 62, November 2013, s. 34.

${ }^{164}$ T. Tardy, The EU: Facing Non-Traditional Threats..., s. 179; S. Blockmans, R.A. Wessel, op. cit., s. 274-275.

${ }^{165}$ Zob. np. J. Wouters, S. de Jong, P. de Man, The EU's Commitment to Effective Multilateralism in the Field of Security: Theory and Practice, Katholieke Universiteit Leuven, Working Paper No. 45, March 2010; P. Koutrakos, The EU Common Security..., s. 80.

${ }^{166}$ J. Koops, op. cit., s. 345.

${ }^{167}$ B. Germond, op. cit., s. 123. 
polityki zagranicznej ${ }^{168}$. Operacja NAVFOR Atalanta natomiast wskazuje, że realna jest współpraca UE i NATO, dyskutowana w kontekście cywilnych aspektów zarządzania kryzysowego, w oparciu o ideę „odwróconych Porozumień »Berlin plus «", tzn. takich, które pozwolą NATO korzystać z zasobów cywilnych i policyjnych UE ${ }^{169}$.

Na podstawie art. 43 Traktatu o UE operacje Concordia i Althea można zakwalifikować jako operacje utrzymania pokoju, zaś NAVFOR Atalanta - jako operację humanitarną i ratunkową ${ }^{170}$. Misje cywilne można określić mianem „wojskowego doradztwa i wsparcia” lub „zapobiegania konfliktom i utrzymania pokoju". Można je ująć w trzech kategoriach: wzmacniające (np. EULEX Kosovo, EUCAP Nestor), monitorujące (np. EUMM Gruzja) i wykonawcze (np. EULEX Kosovo). W oficjalnych dokumentach nie dokonuje się takiej kategoryzacji, stwierdzając jedynie, że misje i operacje wchodzą w zakres art. 43 Traktatu o UE. Odmiennie niż w przypadku operacji NATO, nie są to operacje wymuszania pokoju i nie stanowią mechanizmu rozwiązywania konfliktu, tylko raczej stwarzają możliwość osiągnięcia jego politycznego rozwiązania ${ }^{171}$.

Stopniowo UE staje się aktywnym uczestnikiem działań na rzecz bezpieczeństwa w Europie i na świecie ${ }^{172}$. Obecne zaangażowanie UE w zarządzanie kryzysowe wpływa, w znacznym stopniu, na wzajemne relacje pomiędzy Unią a NATO. Przedmiotem ich wspólnego zainteresowania jest bowiem kwestia bezpieczeństwa międzynarodowego. W wielu oficjalnych dokumentach i komunikatach używa się sformułowania, iż „obie organizacje łączą wspólne strategiczne interesy i współpracują w duchu komplementarności i partnerstwa"173 lub ,stworzyły rzeczywiste partnerstwo"174. NATO wprawdzie nie determinuje roli, jaką odegra UE w tym zakresie, do pewnego stopnia nawet ogranicza działalność UE w dziedzinie zarządzania kryzysowego ${ }^{175}$.

${ }^{168}$ A. de Vasconcelos, Introduction - 2020..., s. 24.

${ }^{169}$ E. Lagadec, Transatlantic Relations in the 21 $1^{\text {st }}$ Century: Europe, America and the Rise of the Rest, Routledge 2012, s. 121-122; S. Clément-Noguier, Analysis: New Challenges, Tough Choices, "NATO Review" 2006, No. 4, www.nato.int/docu/review/2006/issue4/english/analysis2. html [data dostępu: 20.08.2016].

${ }^{170}$ T. Tardy, CSDP in Action What Contribution to International Security?, "Challiot Papers" May 2015, No. 134, s. 22.

${ }^{171}$ Ibidem, s. 23-25.

${ }^{172}$ T. Renard, European Union: A New Security Actor?, European University Institute, Robert Schuman Centre for Advanced Studies, Global Governance Programme-99, EUI Working Paper RSCAS 2014/45, s. 1.

${ }^{173}$ NATO-EU: a Strategic Partnership, www.nato.int/cps/en/natohq/topics_49217.htm?selected Locale=uk [data dostępu: 20.08.2016]; Joint statement by the NATO Secretary General Jens Stoltenberg and the President of the European Commission Jean-Claude Juncker, 16 June 2015, www. nato.int/cps/en/natohq/opinions_120675.htm [data dostępu: 20.08.2016].

${ }_{174}$ Zob. S.J. Smith, op. cit., s. 243.

${ }^{175}$ M.J. Stewart, European Union Conflict Prevention and the European Security Architecture, [w:] EU Conflict Prevention and Crisis Management: Roles, Institutions, and Policies, eds. E. Gross, A.E. Juncos, Routledge 2011, s. 37. 
W świetle koncepcji strategicznej, przyjętej w listopadzie 2010 r. w Lizbonie, NATO przewiduje budowę własnych zdolności w kontekście cywilnych aspektów zarządzania kryzysowego ${ }^{176}$. Ponadto NATO i UE równolegle stworzyły siły szybkiego reagowania - grupy bojowe UE oraz NRF Sojuszu, przedstawiły też podobne koncepcje dotyczące zwiększenia zdolności - tzw. inicjatywa Ghent i Smart Defence. Działając na tym samym obszarze, prowadzą jednak odrębne operacje, a ich współpraca $\mathrm{w}$ terenie odbywa się $\mathrm{w}$ drodze nieformalnych porozumien ${ }^{177}$. Brak koordynacji działań i współpracy spowodował, że obie organizacje nie działały skutecznie w operacjach zarządzania kryzysowego ${ }^{178}$. Znacznie lepiej układa się współpraca pomiędzy personelem obu organizacji oraz w kontaktach Wysokiego Przedstawiciela do spraw Zagranicznych i Polityki Bezpieczeństwa z Sekretarzem Generalnym NATO ${ }^{179}$.

W obliczu nowych wyzwań i zagrożeń NATO przyjęło na szczycie w Walii we wrześniu 2014 r. Plan gotowości do działania (Readiness Action Plan), który zawiera środki gwarantujące bezpieczeństwo w postaci natychmiastowego zwiększenia obecności i działalności wojskowej Sojuszu na wschodnich flankach NATO oraz środki adaptacyjne - jest to długoterminowy plan wprowadzania zmian w siłach i strukturach dowodzenia NATO, tak by mogło szybko reagować na występujące zagrożenia ${ }^{180}$. Podkreślono w nim, że działania UE i NATO, mające na celu zwiększenie zdolności obronnych, są komplementarne. W związku z destabilizacją Ukrainy i aneksją Krymu przez Rosję NATO poparło sankcje nałożone na Rosję przez UE. W celu wzmocnienia NRF utworzono Połączone Siły Zadaniowe Bardzo Wysokiej Gotowości (Very High Readiness Joint Task Force - VJTF). VJTF to nowe siły Sojuszu gotowe do działania w ciągu kilku dni, w szczególności na peryferiach NATO $^{181}$. Nie oznacza to jednak budowy nowych zdolności, a jedynie nadanie pełnej skuteczności już istniejącym ${ }^{182}$. Podobnie UE przedstawiła Koncepcję szybkiej odpowiedzi militarnej (Military Rapid Response - MRR), która obejmuje wszystkie powiązane ze sobą środki i działania w dziedzinie: wywiadu, procesów decyzyjnych, planowania, tworzenia i rozmieszczenia sił, łącznie z dostępnością zdolności i zasobów oraz różnymi konfiguracjami sprawowania dowództwa i kontroli ${ }^{183}$, tak

${ }^{176}$ Strategic Concept 2010, pkt 25.

${ }^{177}$ Zob. N. Gaeger, op. cit., s. 157-180; N. Graeger, K.M. Haugevik, op. cit., s. 743-757; T. Tardy, CSDP in Action What Contribution to International Security?, s. 30.

${ }^{178}$ S.C. Hoffman, Overlapping Institutions in the Realm of International Security: The Case of NATO and ESDP, "Perspectives on Politics" 2009, Vol. 7, No. 1, DOI: http://dx.doi.org/10.1017/ s1537592709090070, s. 45-46.

${ }^{179}$ S.J. Smith, op. cit., s. 248.

${ }^{180}$ NATO's Readiness Action Plan, North Atlantic Treaty Organization Fact Sheet, May 2015.

${ }^{181}$ www.nato.int/cps/en/natohq/official_texts_112964.htm [data dostępu: 20.08.2016], pkt. $8,14,19$.

${ }^{182}$ C. Mölling, op. cit., s. 23.

${ }^{183}$ Zob. EU Concept for Military Command and Control, Brussels, 24 September 2012, 10688/2/08 REV 2 COSDP 540. 
by w ciągu 30 dni odpowiedzieć na sytuację kryzysową. MRR stanowi podstawowy dokument dla wszystkich pozostałych koncepcji odnoszących się do szybkiej odpowiedzi na kryzysy: grup bojowych, lądowych, morskich i powietrznych ${ }^{184}$.

Nie udało się jednak UE wzmocnić swojej pozycji w NATO. Państwa członkowskie UE w NATO nie uzgadniają swoich stanowisk i nie prezentują jednolitego stanowiska w określonej sprawie ${ }^{185}$. Relacje pomiędzy UE a NATO są czynnikiem powodującym stagnację w dziedzinie $\mathrm{WPBiO}^{186}$.

Skuteczne budowanie pokoju wymaga spójnej współpracy różnych organizacji międzynarodowych. Cel ten można osiągnąc przez koordynację działań pomiędzy organizacjami. Wymaga to także stworzenia systemu wspólnego planowania operacji i częstszych spotkań na wysokim szczeblu. Realizacja tego zadania zależy od woli politycznej państw członkowskich danej organizacji. UE i NATO są do pewnego stopnia „zakładnikami” państw członkowskich, które traktują te organizacje jako forum do realizacji partykularnych interesów ${ }^{187}$. Organizacje te nie podjęły skutecznych działań, by zasłużyć na zaufanie państw członkowskich. Państwa są przekonane, że nikt inny nie zadba lepiej o ich interesy niż one same. $\mathrm{Z}$ tego powodu też zawierają liczne umowy bilateralne, które regulują zasady współpracy w różnych obszarach, w tym bezpieczeństwa (np. NORDEFCO zawarte w 2009 r. pomiędzy państwami nordyckimi ${ }^{188}$ czy francusko-brytyjskie traktaty zawarte w 2010 r. na 50 lat w kwestii współpracy w dziedzinie bezpieczeństwa i obrony $)^{189}$. Operacje prowadzone przez NATO i UE wskazują, że poszczególne państwa nie posiadają zdolności do samodzielnego prowadzenia działań ${ }^{190}$, zatem współdziałanie w dziedzinie bezpieczeństwa jest niezbędne w kontekście tzw. wszechstronnego podejścia do kwestii bezpieczeństwa (comprehensive approach), wymagającego skutecznego stosowania środków cywilnych i wojskowych ${ }^{191}$.

${ }^{184}$ EU Military Rapid Response Concept, Brussels, 8 January 2015, 17036/1/14 REV 1 CSDP/ PSDC 745, EEAS 02168/4/14 REV 4.

${ }^{185}$ A. de Vasconcelos, Europe's NATO, "European Union Institute for Security Studies" 2009, No. 29 , s. 1.

${ }^{186}$ N. Gnesotto, The Need for a More Strategic EU, [w:] What Ambitions for European Defence in 2020?, s. 31.

${ }^{187}$ Zob. V. Pertusot, European Defence: Minilateralism is Not the Enemy, [w:] The Common Security and Defence Policy: Nationals Perspectives, s. 100-103; C. Major, C. Mölling, The Dependent State(s) of Europe: European Defency in Year Five of Austerity, [w:] The State of Defence in Europe: State of Emergency?, s. 16.

${ }^{188}$ Zob. www.nordefco.org/The-basics-about-NORDEFCO [data dostępu: 20.08.2016].

${ }^{189}$ Treaty between the United Kingdom of Great Britain and Northern Ireland and the French Republic for Defence and Security Co-operation, London, 2 November 2010, Treaty Series No. 36 (2011), Cm 8174, www.official-documents.gov.uk [data dostępu: 18.03.2016].

${ }^{190}$ C. Major, C. Mölling, op. cit., s. 16.

${ }^{191}$ Zob. www.nato.int/cps/en/natohq/topics_49217.htm [data dostępu: 20.08.2016]. 
Arabska wiosna ludów i aneksja Krymu przez Rosję dowodzą, że sąsiedztwo UE jest niestabilne i stwarza zagrożenie zarówno dla bezpieczeństwa europejskiego, jak i globalnego. Niestety, wciąż wiele problemów we wzajemnych stosunkach pomiędzy tymi organizacjami - UE i NATO - pozostaje nierozwiązanych. Zarówno nowa Globalna strategia polityki zagranicznej i bezpieczeństwa UE Shared Vision, Common Action: A Stronger Europe, przedstawiona w czerwcu 2016 r., jak i Wspólna deklaracja UE i NATO podpisana w dniu 8 lipca 2016 r. w Warszawie przez przewodniczącego Rady Europejskiej D. Tuska, przewodniczącego Komisji Europejskiej J.C. Junckera oraz Sekretarza Generalnego NATO J. Stoltenberga ${ }^{192}$, określają, w jaki sposób wspólnie UE i NATO mogą skutecznie odpowiadać na obecnie występujące zagrożenia w dziedzinie bezpieczeństwa. W dokumentach tych po raz kolejny podkreślono potrzebę pogłębienia współpracy i koordynacji działań UE z NATO w dziedzinie bezpieczeństwa. Stwierdzono także, że przez spójny, komplementarny i międzyoperacyjny rozwój zdolności obronnych, wzmocnienie przemysłu obronnego, intensyfikację badań w dziedzinie obronności, wspólnie prowadzone ćwiczenia, działania prowadzone w celu budowy zdolności obronnych partnerów UE i NATO, zwalczanie hybrydowych i cyberzagrożeń oraz podniesienie bezpieczeństwa morskiego nastąpi wzmocnienie współpracy pomiędzy UE i NATO w dziedzinie bezpieczeństwa międzynarodowego. Jednocześnie uznano w tym zakresie konieczność zachowania przez UE i NATO pewnej autonomii w celu zapewnienia pokoju i bezpieczeństwa zarówno na terytoriach państw członkowskich UE i NATO, jak i poza ich granicami ${ }^{193}$.

\section{BIBLIOGRAFIA}

Adler-Nissen R., The European Security and Defence Policy: from Distant Dream to Joint Action, [w:] International Organizations: Their Role in Conflict Management, ed. P. Dahl Thruelsen, Royal Danish Defence College, Copenhagen 2009.

Aybet G., A European Security Architecture after the Cold War: Questions of Legitimacy, Palgrave Macmillan 2000, DOI: http://dx.doi.org/10.1057/9780230598553.

Baggett A., Development of the European Union Common Defense and Its Implications for the United States and NATO, "Georgia Journal of International and Comparative Law" 2003, Vol. 31, No. 2.

Barcikowska A., EU Battlegroups - Ready to Go?, "European Union Institute for Security Studies" 2013, No. 40.

Binnendijk H., Gompert D.C., Kugler R.L., New Military Framework for NATO, "Defense Horizons" 2005, Vol. 48, [w:] New Military Framework for NATO: Reprint of an Issue of Defense Horizons, May 2005, Vol. 48, Diane Publishing 2008.

Blockmans S., Wessel R.A., The European Union and Crisis Management: Will the Lisbon Treaty Make the EU More Effective?, "Journal of Conflict and Security Law" 2009, Vol. 14, No. 2.

${ }^{192}$ Zob. www.consilium.europa.eu/en/meetings/international-summit/2016/07/08-09/ [data dostępu: 20.08.2016].

${ }^{193}$ Szerzej https://europa.eu/globalstrategy/en [data dostępu: 20.08.2016]. 
Brosing M., The Interplay of International Institutions in Kosovo between Convergence, Confusion and Niche Capabilities, "European Security" 2011, Vol. 20, No. 2,

DOI: http://dx.doi.org/10.1080/09662839.2011.564614.

Cameron F., The EU and International Organisations: Partners in Crisis Management, "European Policy Center Issue Paper", 24 October 2005, No. 41.

Capability Development Plan, www.eda.europa.eu/what-we-do/eda-priorities/strategies/Capabilities [data dostępu: 20.08.2016].

Clément-Noguier S., Analysis: New Challenges, Tough Choices, "NATO Review" 2006, No. 4, www.nato.int/docu/review/2006/issue4/english/analysis2.html [data dostępu: 20.08.2016].

Coelmont J., CSDP: There is Something There that Was Not Before, [w:] The Common Security and Defence Policy: Nationals Perspectives, ed. D. Fiott, Egmont-Royal Institute for International Relations, Egmont Papers, Brussels, May 2015.

Cziomer E., Instytucjonalizacja wspótpracy transatlantyckiej: problemy $i$ wyzwania, [w:] Bezpieczeństwo międzynarodowe w XXI wieku. Wybrane problemy, Kraków 2010.

Deighton D., Through the Glass Ceiling: The EU as Developing Security Regime for Europe?, "Croatian International Relations Review" 2000, Vol. 6, No. 20/21.

Drent M., From 'Effective' to 'Selective Multilateralism': the European Union's Relations with NATO, [w:] The EU and Effective Multilateralism: Internal and External Reform Practices, eds. E. Drieskens, L.G. van Schaik, Routledge 2014.

Dursun-Ozkanca O., Does it Take Four to Tango? A Comparative Analysis of International Collaboration on Peacebuilding in Bosnia and Herzegovina and Kosovo, "Journal of Balkan and Near Eastern Studies" 2010, Vol. 12, No. 4.

Egger C., Being the Best at Winning the Peace. NATO and EU Rival Development of a Comprehensive Approach to Crisis Management, 2013, https://halshs.archives-ouvertes.fr/halshs-00804164 [data dostępu: 20.08.2016].

Engberg K., The EU and Military Operations: A Comparative Analysis, Routledge 2013.

EU-US Summit, Joint Statement, Brussels, 26 March 2014, 140326/02.

European Defence Agency, EDA's Pooling\&Shering, Fact Sheet, www.eda.europa.eu/docs/defaultsource/eda-factsheets/final-p-s_30012013_factsheet_cs5_gris [data dostępu: 20.08.2016].

European Union, European Security and Defence Policy, EU Naval Operation against Piracy (EU NAVFOR Somalia - Operation ATALANTA), www.iflos.org/media/34138/090422-factsheet eu_navfor_somalia-version6_en.pdf [data dostępu: 20.08.2016].

Factsheet on EUNAVFOR MED Mission, European Union Naval Force - Mediterranean Operation Sophia, http://eeas.europa.eu/csdp/missions-and-operations/eunavfor-med/index_en.htm [data dostępu: 20.08.2016].

Final Communiqué of the Ministerial Meeting of the North Atlantic Council, Press Communiqué M-NAC-1(96)63 - 3 June 1996.

Force Re-Structuring, www.euforbih.org/index.php?option=com_content\&view=article\&id=2821 [data dostępu: 20.08.2016].

Gebhard C., Smith S.J., The Two Faces of EU-NATO Cooperation: Counter-Piracy Operations off the Somali Coast, "Cooperation and Conflict" 2015, Vol. 50, No. 1, DOI: http://dx.doi.org/10.1177/0010836714532917.

Germond B., The Maritime Dimension of European Security: Seapower and the European Union, Palgrave Macmilla 2015, DOI: http://dx.doi.org/10.1057/9781137017819.

Germond B., Smith M.E., Re-Thinking European Security Interests and the ESDP: Explaining the EUs Anti-Piracy Operation, "Contemporary Security Policy" 2009, Vol. 30, No. 3, DOI: http://dx.doi.org/10.1080/13523260903327741.

Gnesotto N., The Need for a More Strategic EU, [w:] What Ambitions for European Defence in 2020?, ed. A. de Vasconcelos, European Union Institute for Security Studies, Report No. 8, November 2010. 
Gourlay C., The Politics of EU Civilian Interventions and the Strategic Deficit of the CSDP, Geneva Center for the Democratic Control of Armed Forces, Brussel-ISIS Europe, EU Crisis Management Papers, September 2011, with revised Chart, September 2012.

Graeger N., Security. EU-NATO Relations: Informal Cooperation as a Relations: Informal Cooperation as a Common Lifestyle, [w:] The European Union with(in) International Organisations: Commitment, Consistency, and Effects Across Time, ed. A. Orsini, Ashgate 2014.

Graeger N., Haugevik K.M., The EU's Performance with and within NATO: Assessing Objectives, Outcomes and Organisational Practices, "European Integration" 2011, Vol. 33, No. 6.

Graeger N., Tood J., Still a "Strategic" EU-NATO Partnership? Bridging Governance Challenges through Practical Cooperation, "PISM Policy Paper" 2015, No. 21 (123).

Grevi G., EULEX Kosovo: The EU Rule-of-Law Mission in Kosovo (EULEX Kosovo), [w:] European Security and Defence Policy. The First 10 Years (1999-2009), eds. G. Grevi, D. Helly, D. Keohane, European Union Institute for Security Studies, Paris 2009.

Gross E., Peacebuilding in 3D: EU and US Approaches, "Chaillot Papers" 2013, No. 130.

Helly D., EU NAVFOR Somalia: The EU Military Operation Atalanta, [w:] European Security and Defence Policy. The First 10 Years (1999-2009), eds. G. Grevi, D. Helly, D. Keohane, European Union Institute for Security Studies, Paris 2009.

Henius J., MacDonald J.L., Smart Defence: A Critical Appraisal, NATO Defence College, NDC Forum Papers Series, Rome, March 2012.

Hoffman S.C., Overlapping Institutions in the Realm of International Security: The Case of NATO and ESDP, "Perspectives on Politics" 2009, Vol. 7, No. 1,

DOI: http://dx.doi.org/10.1017/s1537592709090070.

http://eeas.europa.eu/csdp/missions-and-operations/eunavfor-med/index_en.htm [data dostępu: 20.08.2016].

http://eur-lex.europa.eu/legal-content/EN/TXT/?uri=URISERV:133243 [data dostępu: 20.08.2016].

http://europa.eu/globalstrategy/en [data dostępu: 20.08.2016].

http://eu-un.europa.eu/articles/en/article_1871_en.htm [data dostępu: 20.08.2016].

http://oceansbeyondpiracy.org/matrix/shared-awareness-and-deconfliction-shade [data dostępu: 20.08.2016].

http://oide.sejm.gov.pl/oide/index.php?option=com_content\&view $=$ article\&id=14815:traktaty\&cat id=22\&Itemid=940\#D [data dostępu: 20.08.2016].

Ioannides I., EUPOL Proxima/EUPAT (Fyrom): The EU Police Mission (EUPOL Proxima) and European Union Police Advisory Team (EUPAT) in the Former Yugoslav Republic of Macedonia, [w:] European Security and Defence Policy. The First 10 Years (1999-2009), eds. G. Grevi, D. Helly, D. Keohane, European Union Institute for Security Studies, Paris 2009.

"Joint Paper by France, Germany and the United Kingdom" Naples, 29 November 2003, [w:] From Copenhagen to Brussel. European Defence: Core Documents, Vol. 4, compiled A. Missiroli, "Chaillot Papers" December 2003, No. 67.

Joint statement by the NATO Secretary General Jens Stoltenberg and the President of the European Commission Jean-Claude Juncker, 16 June 2015, www.nato.int/cps/en/natohq/opinions_120675.htm [data dostępu: 20.08.2016].

Kanis G.J., Ettinger M.R. van, Operational Assessment of a NATO Response Force, http://streitcouncil.org/uploads/PDF/Operational\%20Assessment\%20of\%20NATO\%20Response $\% 20$ Force.pdf [data dostępu: 20.08.2016].

Keohane D., ESDP and NATO, [w:] European Security and Defence Policy. The First 10 Years (19992009), eds. G. Grevi, D. Helly, D. Keohane, European Union Institute for Security Studies, Paris 2009.

Keohane D., EUFOR Althea (Bosnia and Hercegovina): The European Union Military Operation in Bosnia and Herzegovina (Althea), [w:] European Security and Defence Policy. The First 10 Years (1999-2009), eds. G. Grevi, D. Helly, D. Keohane, European Union Institute for Security Studies, Paris 2009. 
Knauer J., EUFOR Althea: Appraisal and Future Perspectives of the EU's Former Flagship Operation in Bosnia and Herzegovina, College of Europe, Department of EU International Relations and Diplomacy Studies, EU Diplomacy Paper 07/2011.

Koops J.A., The European Union as an Integrative Power: Assessing the EU's 'Effective Multilateralism'Towards NATO and the United Nations, Institute for European Studies, Vrije Universiteit Brussel 2011.

Koutrakos P., EU International Relations Law, Modern Studies in European Law, Bloomsbury, Hart Publishing 2015.

Koutrakos P., The EU Common Security and Defence Policy, Oxford 2013,

DOI: http://dx.doi.org/10.1093/acprof:oso/9780199692729.001.0001.

Lagadec E., Transatlantic Relations in the $21^{\text {st }}$ Century: Europe, America and the Rise of the Rest, Routledge 2012.

Landman L., The EU Maritime Security Strategy Promoting or Absorbing European Defence Cooperation?, Clingendael Policy Brief, April 2015.

Larik J., Europe's Fight Against Piracy: From the Barbary Coast to Operation Atalanta, Fondation Pierre du Bois, Papiers d'actualité/Current Affairs in Perspective, Mai 2013, No. 4.

Lasconjarias G., The NRF: from a Key Driver of Transformation to a Laboratory of the Connect Forces Initiative, NATO Defence College's Research Paper No. 88, January 2013.

Lynch D., Missiroli A., ESDP Operations, European Union Institute for Security Studies, www. peacepalacelibrary.nl/ebooks/files/09-dvl-am.pdf [data dostępu: 20.08.2016].

Madelein K. Albright, US Secretary of State 'The Right Balance Will Secure NATO's Future', "Financial Times", 7 December 1998, [w:] From St-Malo to Nice European Defence: Core Documents, compiled M. Rutten, "Chaillot Papers" May 2001, No. 47.

Major C., Mölling C., The Dependent State(s) of Europe: European Defency in Year Five of Austerity, [w:] The State of Defence in Europe: State of Emergency?, eds. S. Biscop, D. Fiott, Egmont - Royal Institute for International Relations, Egmont Papers No. 62, November 2013.

Mattellaer A., Coelmont J., Modern European Operations: From Phoney Wars to Sickle Cuts, [w:] The State of Defence in Europe: State of Emergency?, eds. S. Biscop, D. Fiott, Egmont - Royal Institute for International Relations, Egmont Papers No. 62, November 2013.

McLaren J.G., Europe's Efforts to Develop an Autonomous Defense Capability. A Constitution for Europe, and the Implications for NATO, "Columbia Journal of European Law" 2005, Vol. 11, No. 3.

Medcalf J., Cooperation between the EU and NATO, "Studies in Contemporary History and Security Policy" 2003, Vol. 11, No. 1.

Missorili A., EU-NATO Cooperation in Crisis Management: No Turkish Delight for ESDP, "Security Dialogue" 2002, Vol. 33, No. 1.

Moens A., European Defence and NATO: the Case for New Governance, "International Journal" 2001, Vol. 56, No. 2.

Mölling C., Study: State of Play of the Implementation of EDA's Pooling and Sharing Initiatives and its Impact on the European Defence Industry, European Parliament, Policy Department, Directorate-General for External Policies, EP/EXPO/B/SEDE/FWC/2013-08/Lot6/03, June 2015 -PE 534.988.

Musliu V., Geci S., Deconstructing and Defining EULEX, "Central European Journal of International and Security" 2014, Vol. 8, No. 1.

NATO Military Policy on Civil-Military Co-operation, MC 411/1, www.nato.int/ims/docu/mc4111-e.htm [data dostępu: 20.08.2016].

NATO-EU: a Strategic Partnership, www.nato.int/cps/en/natohq/topics_49217.htm?selectedLocale=uk [data dostępu: 20.08.2016].

Oaks M., European Defence: From Pörtschach to Helsinki, House of Commons Library, Research Paper 00/20, 21 February 2000. 
Palm T., Normative Power and Military Means: The Case of the UE in FYR Macedonia, [w:] New Approaches to EU Foreign Policy, eds. M. Wilga, I.P. Karolewski, Routledge 2014.

Pertusot V., European Defence: Minilateralism is Not the Enemy, [w:] The Common Security and Defence Policy: Nationals Perspectives, ed. D. Fiott, Egmont-Royal Institute for International Relations, Egmont Papers, Brussels, May 2015.

Pop A., NATO and the European Union: Cooperation and Security, "NATO Review" 2007, www. nato.int/docu/review/2007/Partnerships_Old_New/NATO_EU_cooperation_security/EN/index.htm [data dostępu: 20.08.2016].

Reichard M., Some Legal Issues Concerning the EU-NATO Berlin Plus Agreement, "Nordic Journal of International Law" 2004, Vol. 73, No. 1, DOI: http://dx.doi.org/10.1163/157181004323056383.

Renard T., European Union: A New Security Actor?, European University Institute, Robert Schuman Centre for Advanced Studies, Global Governance Programme-99, EUI Working Paper RSCAS 2014/45.

Roach A., Countering Piracy off Somalia: International Law and International Institutions, "American Journal of International Law" 2010, Vol. 104, No. 3.

Rodt A.P., Taking Stock of EU Military Conflict Management, "Journal of Contemporary European Research" 2011, Vol. 7, No. 1.

Rotfeld A.D., The OSCE Role in Cooperation in NATO and the UE in Southeastern Europe, "Croatian International Relations Review" 2000, Vol. 6, No. 21/22.

Schmitt B., European Capabilities Action Plan (ECAP), European Union Institute for Security Studies, http://bdi.mfa.government.bg/info/Module $\% 2002 \% 20 \% 20$ Diplomacia $\% 20$ na $\% 20$ ES/dopalnitelna\%20literatura/ECAP\%20process.pdf [data dostępu: 20.08.2016].

Silvestri S., The UE, NATO, and the Use of Force: A Division of Labour, [w:] What Do Europeans Want from NATO?, ed. A. de Vasconcelos, European Union Institute for Security Studies, Report No. 8, November 2010.

Smith S.J., EU-NATO Cooperation: A Case of Institutional Fatigue?, "European Security" 2011, Vol. 20, No. 2, DOI: http://dx.doi.org/10.1080/09662839.2011.557771.

Sperling J., The European Union and NATO: Subordinate Partner, Cooperative Pillar, Competing Pole, [w:] The EU Presence in International Organizations, eds. S. Blavoukos, D. Bourantonis, Routledge 2011.

Spernbauer M., EU Peacebuilding in Kosovo and Afghanistan: Legality and Accountability, Martinus Nijhoff Publishers 2014, DOI: http://dx.doi.org/10.1163/9789004265714.

Spernbauer M., EULEX Kosovo: The Difficult Deployment and Challenging Implementation of the Most Comprehensive Civilian EU Operation to Date, "German Law Journal" 2010, Vol. 11, No. 8.

Stabilizations Force Transfer of Authority, 5 October 2004 (pdf), www.nato.int/sfor [data dostępu: 20.08.2016].

Stewart M.J., European Union Conflict Prevention and the European Security Architecture, [w:] EU Conflict Prevention and Crisis Management: Roles, Institutions, and Policies, eds. E. Gross, A.E. Juncos, Routledge 2011.

Sturm P., NATO and the EU: Cooperation?, "European Security Review" 2010, Vol. 48, www. natowatch.org/sites/default/files/2010_artrel_445_eu-nato-capabilities.pdf [data dostępu: 20.08.2016].

Tardy T., CSDP in Action What Contribution to International Security?, "Challiot Papers" May 2015, No. 134.

Tardy T., The EU: Facing Non-Traditional Threats in a Globalized World, [w:] Great Powers and Strategic Stability in the 21 $1^{\text {st }}$ Century: Competing Visions of World Order, ed. G.P. Herd, Routledge 2010.

The NATO-UE Strategic Partnership, www.nato.int/docu/comm/2004/06-istanbul/press-kit/006.pdf [data dostępu: 20.08.2016]. 
Treaty between the United Kingdom of Great Britain and Northern Ireland and the French Republic for Defence and Security Co-operation, London, 2 November 2010, Treaty Series No. 36 (2011), Cm 8174, www.official-documents.gov.uk [data dostępu: 20.08.2016].

Varwick J., Koops J.A., The European Union and NATO: 'Shrewd Interorganizationalism' in the Making?, [w:] The European Union and International Organizations, ed. K.E. Jørgensen, Routledge 2009.

Vasconcelos A. de, Europe's NATO, "European Union Institute for Security Studies" 2009, No. 29.

Vasconcelos A. de, Introduction - 2020: Defence Beyond the Transatlantic Paradigm, [w:] What Ambitions for European Defence in 2020?, ed. A. de Vasconcelos, European Union Institute for Security Studies, Report No. 8, November 2010.

Washington Summit Communique, Issued by the Heads of State and Government participating in the meeting of the North Atlantic Council in Washington, D.C. on 24 ${ }^{\text {th }}$ April 1999, NAC-S(99)64.

Wouters J., Jong S. de, Man P. de, The EU's Commitment to Effective Multilateralism in the Field of Security: Theory and Practice, Katholieke Universiteit Leuven, Working Paper No. 45, March 2010.

Wouters J., Neart F., How Effective is the European Security Architecture? Lesson from Bosnia and Kosovo, "International and Comparative Law Quarterly" 2001, Vol. 50, No. 3, DOI: http://dx.doi.org/10.1093/iclq/50.3.540.

www.aco.nato.int/kfor/about-us/natos-role-in-kosovo.aspx [data dostępu: 20.08.2016].

www.aco.nato.int/page13974522.aspx [data dostępu: 20.08.2016].

www.atlanticcommunity.org/Saint-Malo\%20Declaration\%20Text.html [data dostępu: 20.08.2016].

www.consilium.europa.eu/en/meetings/international-summit/2016/07/08-09/[data dostępu: 20.08.2016].

www.consilium.europa.eu/uedocs/cms_data/docs/pressdata/en/esdp/91624.pdf [data dostępu: 20.08.2016].

www.consilium.europa.eu/uedocs/cmsupload/03-11-11\%20berlin\%20plus\%20press\%20note\%20 bl.pdf [data dostępu: 20.08.2016].

www.consilium.europa.eu/uedocs/cmsUpload/2010\%20Headline\%20Goal.pdf [data dostępu: 20.08.2016].

www.eeas.europa.eu/csdp/about-csdp/european-security-strategy [data dostępu: 20.08.2016].

www.eulex-kosovo.eu/en/news/000443.php [data dostępu: 20.08.2016].

www.europarl.europa.eu/summits/fei1_en.htm [data dostępu: 20.08.2016].

www.europarl.europa.eu/summits/hel1_en.htm [data dostępu: 20.08.2016].

www.europarl.europa.eu/summits/kol2_en.htm [data dostępu: 20.08.2016].

www.mc.nato.int/ops/Pages/OOS.aspx [data dostępu: 20.08.2016].

www.mschoa.org/on-shore/about-us [data dostępu: 20.08.2016].

www.nato.int/cps/en/natohq/official_texts_112964.htm [data dostępu: 20.08.2016].

www.nato.int/cps/en/natohq/topics_49217.htm [data dostępu: 20.08.2016].

www.nato.int/cps/en/natolive/topics_48815.htm\#Protector [data dostępu: 20.08.2016].

www.nato.int/cps/en/natolive/topics_48818.htm [data dostępu: 20.08.2016].

www.nato.int/cps/en/natolive/topics_49755.htm [data dostępu: 20.08.2016].

www.nato.int/cps/en/natolive/topics_7932.htm [data dostępu: 20.08.2016].

www.nato.int/ifor/gfa/gfa-home.htm [data dostępu: 20.08.2016].

www.nato.int/ifor/ifor.htm [data dostępu: 20.08.2016].

www.nato.int/docu/update/2004/06-june/e0629f.htm [data dostępu: 20.08.2016].

www.nato.int/sfor [data dostępu: 20.08.2016].

www.natolibguides.info/smartdefence [data dostępu: 20.08.2016].

www.nordefco.org/The-basics-about-NORDEFCO [data dostępu: 20.08.2016].

www.whitehouse.gov/sites/default/files/docs/2015_national_security_strategy.pdf [data dostępu: 20.08.2016].

Xavier A.I., The EU's Battlegroup in Perspective: Addressing Present Challenges for Future Deployments, Austria Institute für Europa-und-Sicherheitspolitik, "Focus" 2013, No. 7.

Yost D.S., NATO and International Organizations, NATO Defense College, Research Division, Rome, September 2007. 


\section{SUMMARY}

The article analyses the role of European Union (EU) and NATO in the system of the international security. The official documents often highlights that EU and NATO are unique and essential partners. Both organisations share common values and have 22 common members. Furthermore, it is stressed that UE and NATO can and should be complementary to one another and help one another in pressing area of international peace and security. Unfortunately co-operation between these both organisations still maintain difficult, complex and challenging problem.

Keywords: European Union; NATO; co-operation; international security

\section{STRESZCZENIE}

W artykule poddano analizie rolę Unii Europejskiej (UE) i NATO w systemie bezpieczeństwa międzynarodowego. W oficjalnych dokumentach często pojawia się stwierdzenie, że UE i NATO to wyjątkowi partnerzy. Obie organizacje łączą wspólne wartości, a 22 państwa członkowskie NATO należą też do UE. Podkreśla się, że UE i NATO mogą, a nawet powinny wzajemnie się wspierać i uzupełniać w dziedzinie międzynarodowego pokoju i bezpieczeństwa. Niestety, współpraca pomiędzy nimi stanowi trudny i złożony problem.

Słowa kluczowe: Unia Europejska; NATO; współpraca; bezpieczeństwo międzynarodowe 